\title{
Role of Behavioral Activation/Inhibition Systems and Life Orientation in HEXACO Personality Dimensions in University Students
}

\author{
Gelavizh Mohammadi ${ }^{1}$, Jahangir Mohammadi ${ }^{2}$, Sajjad Basharpour ${ }^{3}$, Zahra Maghami Sharif ${ }^{4}$, Asma \\ Aghebati $^{5}$ and Fayegh Yousefi ${ }^{6}$ \\ 1. Ph.D. Candidate, Clinical Psychology Department, School of Behavioral Sciences and Mental Health, (Tehran Institute of \\ Psychiatry) Iran University of Medical Sciences, Tehran, Iran. ORCID ID: $\cdots \cdots \cdots \cdot 1-7 \leqslant \vee Y_{-} \leqslant 191$. \\ 2. Ph.D. Candidate, Department of Clinical Psychology, School of Behavioral Sciences, University of Social Welfare and \\ Rehabiliation Sciences, Tehran, Iran. (corresponding author), Tel: 091870446685, Email: jahanmohammadi68@ gmail.com, \\ ORCID ID: $\cdots \cdots-0003-3040-763 X$. \\ 3. Professor of Psychology, Psychology Department, Faculty of Education and Psychology, Mohaqeq-e-Ardabili University,

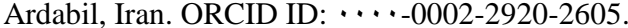 \\ 4. Msc of Psychology, Faculty of Humanities and Social Sciences, Science and Research Branch, Islamic Azad University, \\ Tehran, Iran. ORCID ID: ‥-0002-2184-1226. \\ 5. Assistant Professor, Clinical Psychology Department, School of Behavioral Sciences and Mental Health, (Tehran Institute \\ of Psychiatry) Iran University of Medical Sciences, Tehran, Iran. ORCID ID: …-0002-2117-4582. \\ 6. Associate professor, Department of Psychiatry, Medical Faculty, Kurdistan University Of Medical Sciences, Sanandaj, \\ Iran. ORCID ID: 0000-0001-5503-3326.
}

\begin{abstract}
Background and Aim: The current study was performed to investigate the role of activation/inhibition systems and life orientation in the students' personality traits.

Materials and Methods: This descriptive-correlational study included 370 university students studying for Bachelor, MA and Phd degrees.The participants were selected by multistage cluster sampling. Data were collected by using scale of behavioral activation-inhibition, life orientation testrevised, and HEXACO personality inventory. Using SPSS-21 software, data were analyzed by Spearman correlation coefficient and regression analysis.

Results: among the components of behavioral activation/inhibition systems, punishment was negatively related to extraversion and conscientiousness, while there was a positive correlation between reward and extraversion, agreeableness and conscientiousness. Also a positive correlation was found between entertainment and conscientiousness. Among the components of life orientation, optimism was positively correlated with honesty-humanity, extraversion, conscientiousness, and openness to experience; pessimism was positively correlated with emotionality and negatively correlated with openness to experience and conscientiousness. The results of regression analysis revealed that among personality dimensions of HEXACO, the most frequent variances explained by behavioral activation/inhibition systems and life orientation were conscientiousness (0.17) and openness to experience (0.11), respectively. All the components of behavioral activation/inhibition systems and life orientation could explain 0.53 of HEXACO personality dimensions.
\end{abstract}

Conclusion: Predictions of all of HEXACO personality dimensions by behavioral activation/inhibition systems and life orientation components were significant. Conscientiousness and openness to experience were the most frequent variances explained by behavioral activation/inhibition systems and life orientation among personality dimensions of HEXACO.

Keywords: Behavioral activation system, Behavioral inhibition system, Life orientation, HEXACO personality dimensions

Received: June 9, 2019

Accepted: Jan 11, 2021

How to cite the article: Gelavizh Mohammadi, Jahangir Mohammadi, Sajjad Basharpour, Zahra Maghami Sharif, Asma Aghebati and Fayegh Yousefi. Role of Behavioral Activation/Inhibition Systems and Life Orientation in HEXACO Personality Dimensions in University Students.व́LSJKU 2021; 26(6):93-106.

Copyright (C) 2018 the Author (s). Published by Kurdistan University of Medical Sciences. This is an open access article distributed under the terms of the Creative Commons Attribution-Non Commercial License 4.0 (CCBYNC), where it is permissible to download, share, remix, transform, and buildup the work provided it is properly cited. The work cannot be used commercially without permission from the journal 


\section{نقش سيستمهاى مغزى فعالسازى - بازدارى رفتارى و جهت تيرى زندكى در ابعاد شخصيتى هكز اكو دانشجويان}

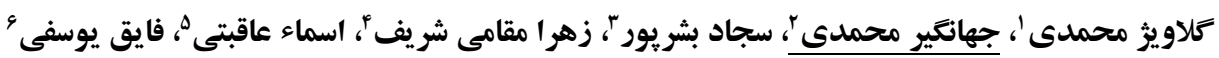

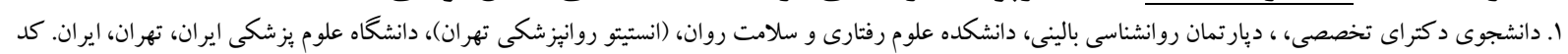
ار كيد:

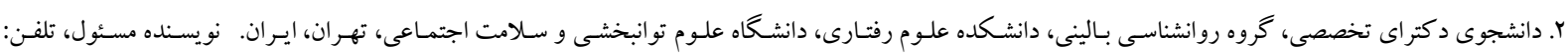

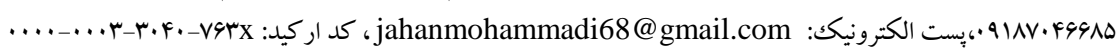

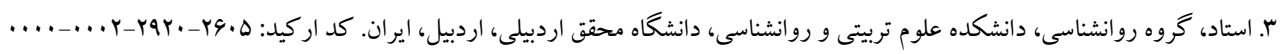

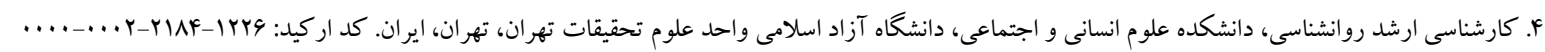

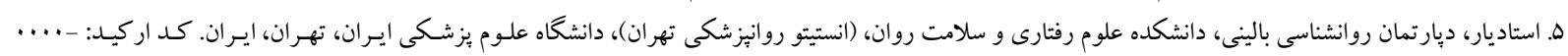

W.r-rIIV-FDAr

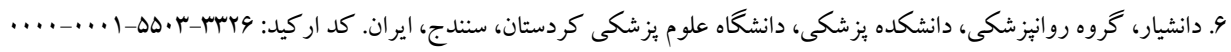
جكيuه زمينه و هدف: يزٔوهش حاضر با هدف بررسى تأثير نقش سيستمهاى مغزى فعالسازى-بازدارى رفتـارى و جهـت گيرى زنـدگى در ابعاد شخصيتى هخزاكو دانشجويان انجام گرفت.

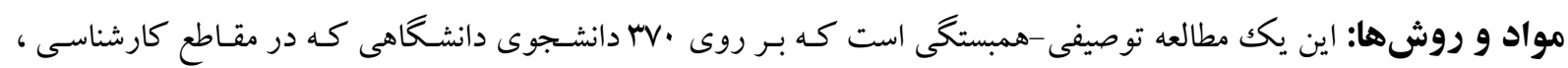

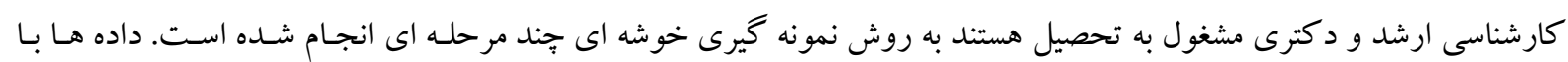

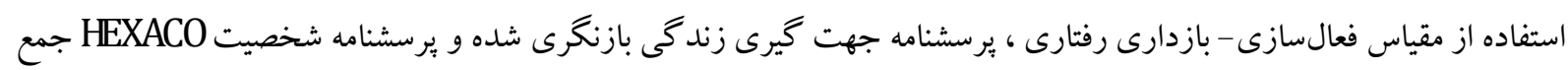

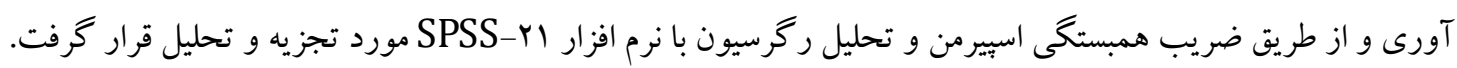
يافته ها: داده ها نشان دادند كه در بين اجزاى سيستم هاى فعال سازى /بازدارى رفتارى، تنبيه با برون گرايى و باوجدان بودن رابطه

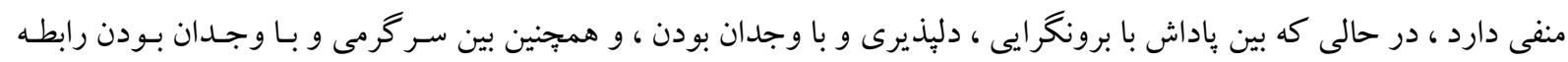

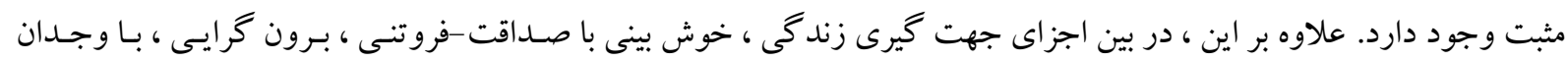

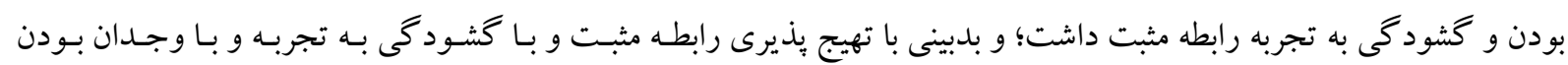

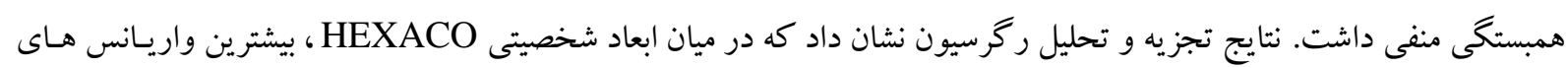
تبين شده توسط سيستم هاى فعال سازى/بازدارى رفتارى، به ترتيب با وجدان بودن(IV/•) و گشودگى به تجربـه (II/•) بودنـد. همـه

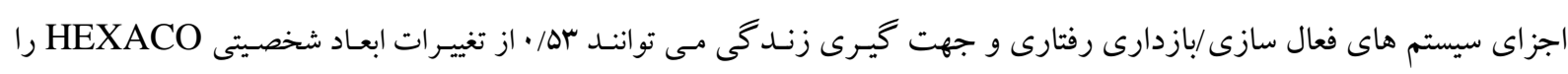
توضيح دهند. نتيجه كيرى: بيش بينى تمام ابعاد شخصيتى هكزاكو توسط مؤلفهاى سيستم مغزى فعالسازى - بـازدارى رفتـارى و جهـت گيرى

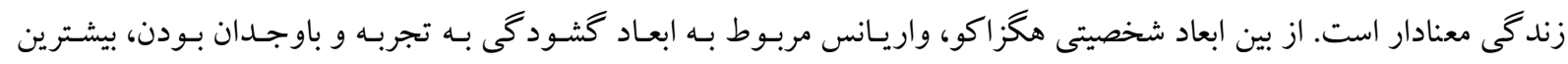
واريانس هايى بود كه توسط متغيرهاى سيستمهاى مغزى فعالسازى-بازدارى رفتارى و جهت گيرى زندكى تبين شدند. كلمات كليلى: سيستم مغزى فعالسازى رفتارى، سيستم مغزى بازدارى رفتارى، جهت گيرى زندگىى، ابعاد شخصيتى هخز اكو

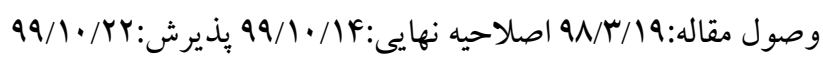


ديخرى درزمينه ابعاد شخصيتى هخز اكو نشان داده است كه.

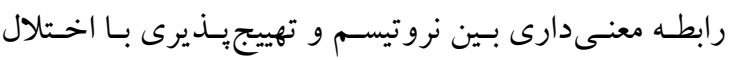

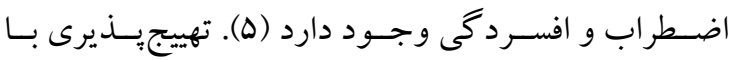

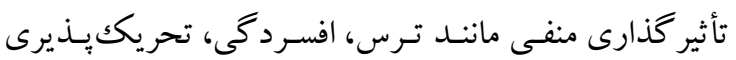

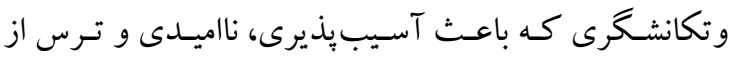

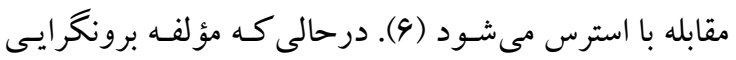

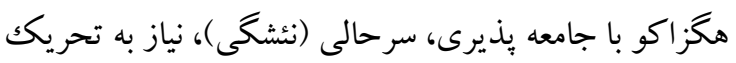
و ظرفيت تجربه احساسات مثبت رابطه دارد (r).

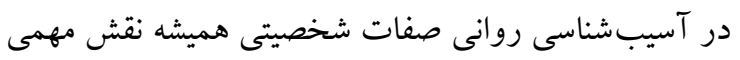
در ويدايش بيمارىهاى جسمى و روانى مـزمن دارد و ايـن

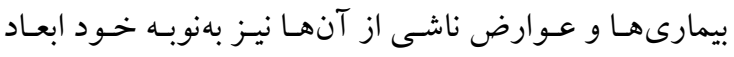
مختلف شخصيت بيمار را تحت تأثير قرار مىدهنـد (V Vو (4). عوامل مختلفى در تعيين اين تفاوتهاى فردى دخيل هستند كه موجب عادات رفتارى و خلقوخوهاى متفاوت در افراد مى شود كه آنها را مستعد سلامت و بيمارى جسمى و روانى مى سازد. يكى از اين تعيين كنندهاى مهم سيستمهاى مغزى و رفتارى است. ميزان و غلبه اين سيستمها در افراد مختلف، متفاوت است و اين امـر زيربنـاى تفاوتهـاى شخصـيتى در افراد است. گرى (^) با معرفى دستخاههاى مغزى در گير در انسواع رفتـار و تجربسهاى ذهنسى - هيجـانى بيـان كـرد كـه هيجانها از طريق بخشهاى مختلفى از مغز تنظيم مىشوند.

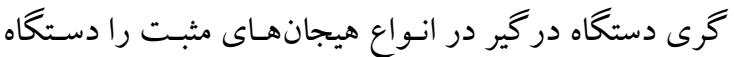
كرايش يا فعالساز و دستگاه در گير در اضطراب را دستخاه بازدارى رفتـارى يـا توقف ناميد. تئسورى ارائهشـده توسط

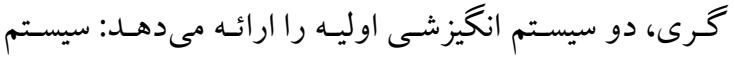
بehavioral Inhibition System, ) بازدارنده رفتارى

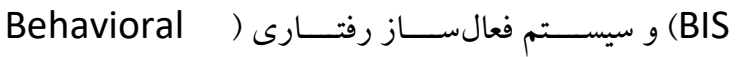
(Activation System, BAS ارائهدهنــده تفاوتهــاى فـردى در حساسـيت دو سيسـتم نورولوزيكى در ياسخهاى آنها به نشانهاى محيطى مـر درتبط اسـت. سيستمهــاى مغـزى رفتـارى در حقيقـت شـيوه نـوين

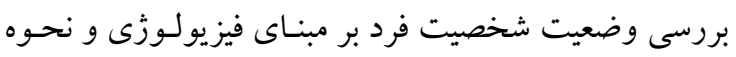
يردازش هاى بايه عصبى دستخاه اعصـاب مر كزى هستيند.
ويز گى هاى شخصيتى را مى توان بـهنوان ابعـاد تفاوتهـاى

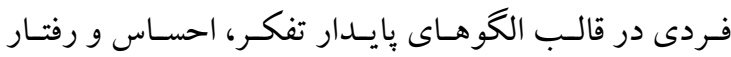
تعريف نمود (1). در آسيبشناسى روانى و ديد كاه تكاملى

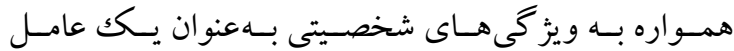

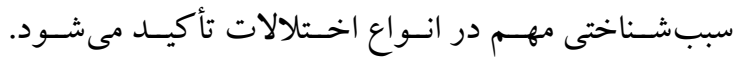
ويز گىهاى شخصيتى كه تركيبى از زنتيك، عو امل موقعيتى

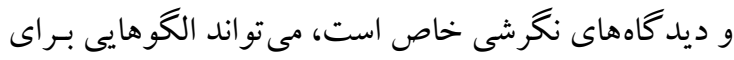
ييشبينى رفتار و حالتهاى روانى فراهم آورد و تفاوتهاى

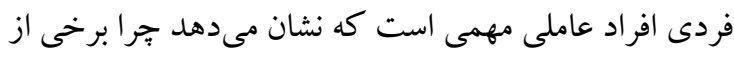

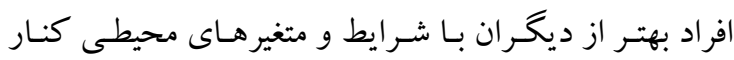

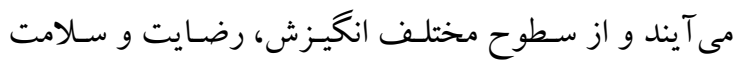
روان برخوردارند (Y). روانشناسان شخصيت در حال نزديكك

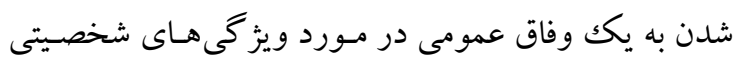
انسان مىباشند: نظريـه شخصـيتى هگز اكى (HEXACO

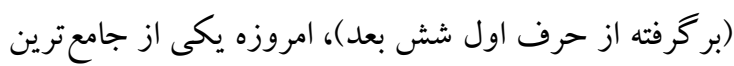

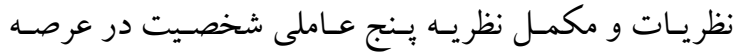

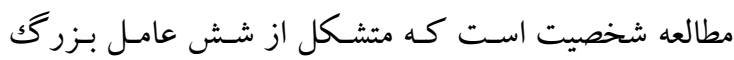
شخصيتى شامل، صداقت - فروتنى، گشـود گى بـه تجربـه،

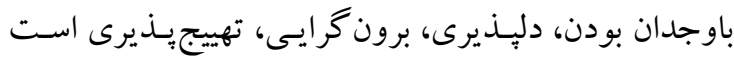

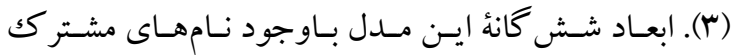

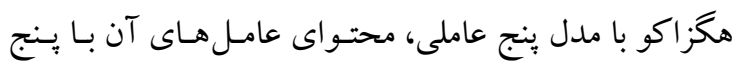

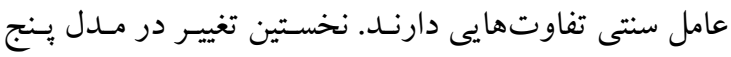

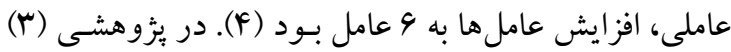

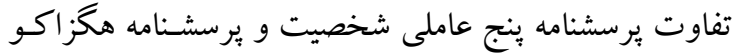

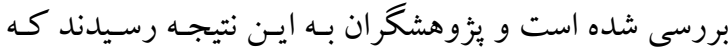
براى بررسى ويزّى هاى شخصيت به طور كلى مى توان از

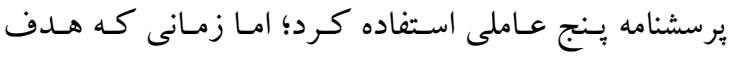
سنجش رفتارهاى مرتبط بـا شخصيت اسـت، بهتر اسـت از از يرسشنامه هخز اكو استفاده شود.

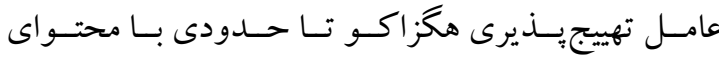
تحريك يذيرى و تندمزاجى مشخص مىشود كه معمـولاً در

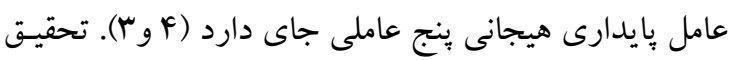


همكاران (19) نيـز نشـان دادنـد فر آينـدهاى شـناختى مانتـد سبككهاى تصـميم گيرى و رفتـارى، تحـت تـأثير مستقيم و

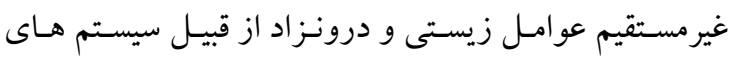
مغزى رفتارى و برترى نيمكرهاى مى باشند.

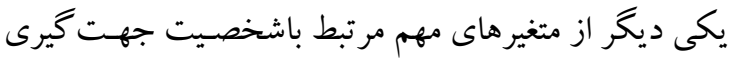

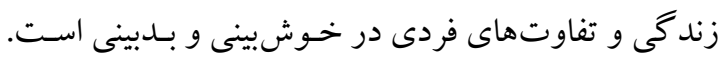

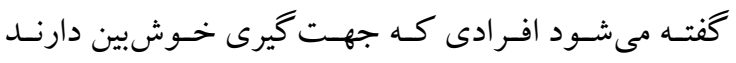

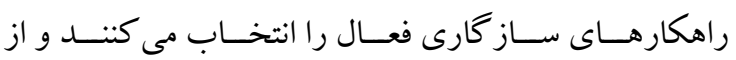
كشودگى به تجربه و هيجانهاى مثبت بالاترى برخوردارنس

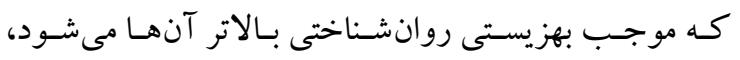

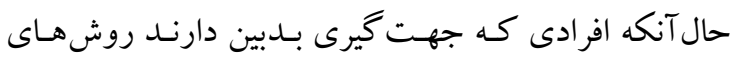

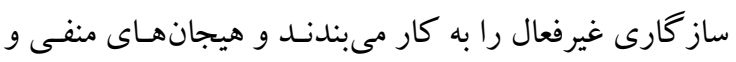

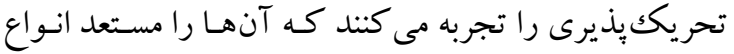

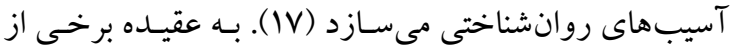

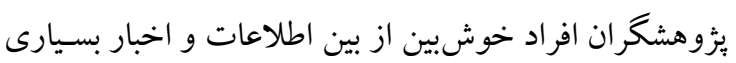

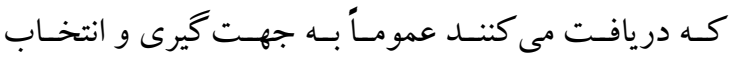

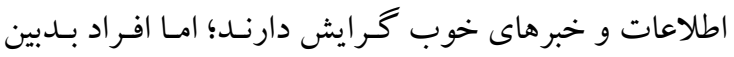
هميشه سو گيرى به دريافت و بردازش اطلاعـات ناخوشايند دارند و انتظار دارند كارها در جهـت نـامطلوب يـيش رود و

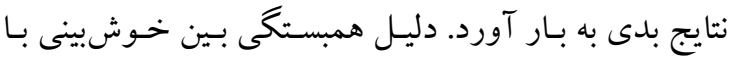

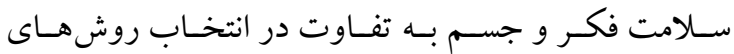
ساز كارى بهوسيله افراد خوشبين و بـدبين وابستهـ مىباشـد،

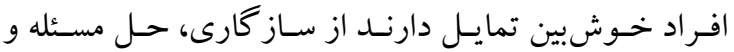
روشهاى حمايت اجتمـاعى بهرهجوينـد و نيز بـر جنبـهاى

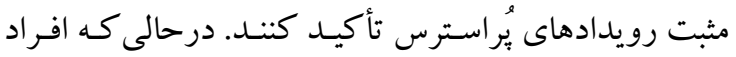
بدبين مايلند، روش ساز كارى انكار و اجتناب را برگزينتـد و

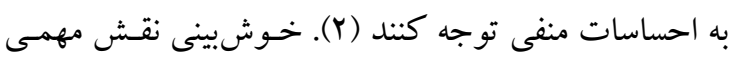

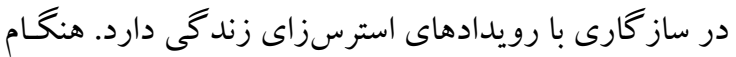
روبهرو شدن با يكك جالش، افراد خوشيين حالت اطمينان و بايدار دارند (حتى اخر ييشرفت، سخت يـا كنـد باشــد)؛ امـا

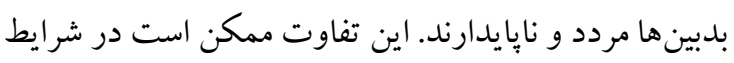

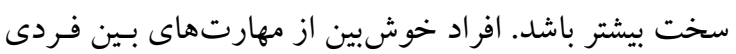

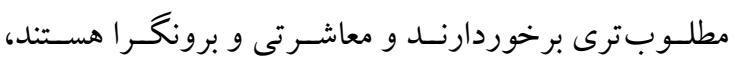

موتوئى و همكـاران (9)، سيستم هـاى بازدارنــده رفتـارى و

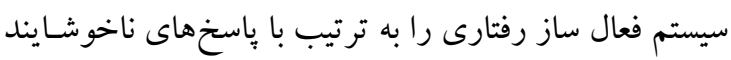

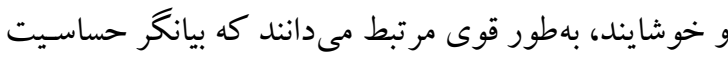

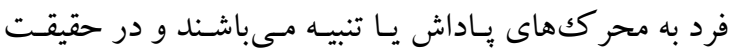

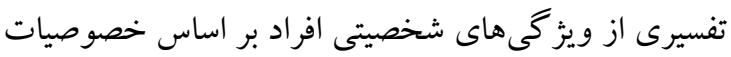

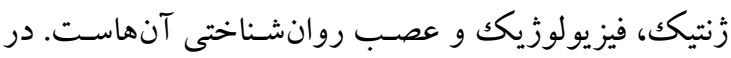

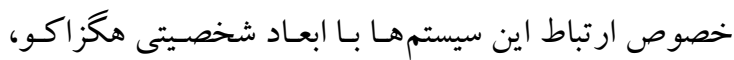

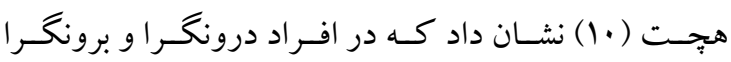
سيستمهاى فعالسـاز و بازدارنـده بهصورت متفــاوت عمـل

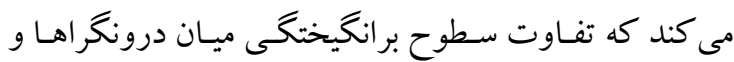
برونخراها زير ساز تفاوتهاى مشاهدهشده ميـان ايـن گرووه در باسخهايشـان بـه محسيط و عملكــد در تكـاليف اسـت. تفاوت هاى شخصيتى و عوامل روانى مانند هيجـانيــيرى و

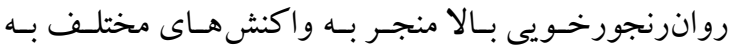

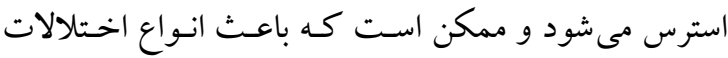

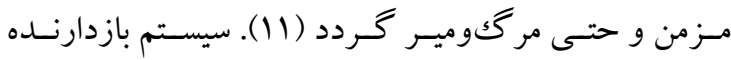
رفتارى به رفتار مستقيم در باسخ به تهلديدها و محر كك جديد فرض شده درحالى كه سيستم فعالسـاز رفتـارى، رفتار را در ياسخ به انگيزهها و شوقها تعديل مى كند. تحقيق ديخرى از

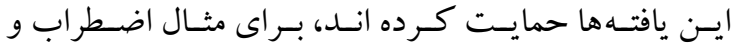
ويز گى هاى شخصيتى روانرنجور نتيجه فعاليت بيشتر سيستم بازدارى رفتارى اسـت و افراد برونخـرا در مقايسه بـا افراد

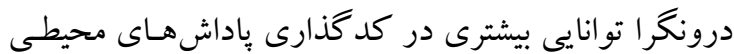

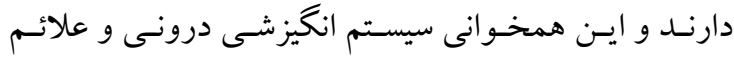

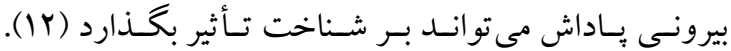

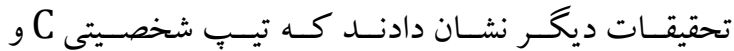
درونخر ايـى بهوســــله سيسـتمهاى بــازدارى رفتـارى و

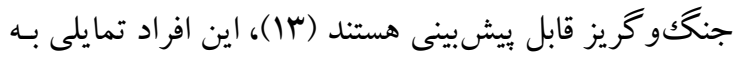

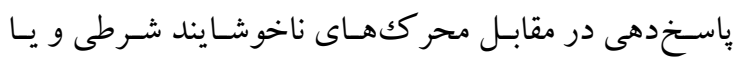
غيرشرطى ندارند (F) (I). تحقيقات نشان داده است كه فعاليت بيشازانـدازه سيستم بـازدارى، منجر بـه صفات شخصيتى

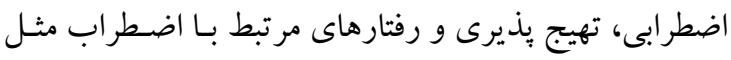

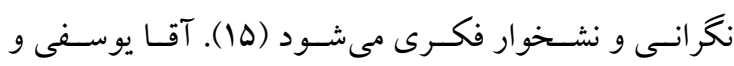


مطالعه حاضـر يـك يـزوهش توصيفى و از نوع همبستخكى

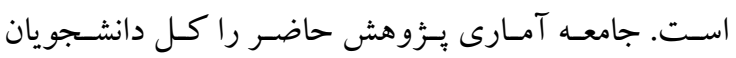

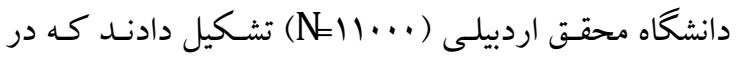
سال تحصيلى

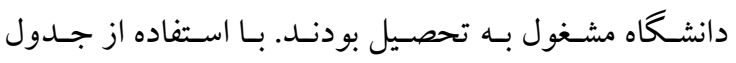

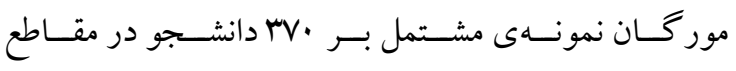

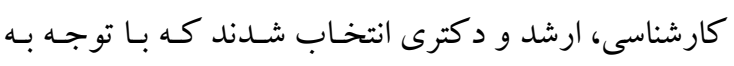

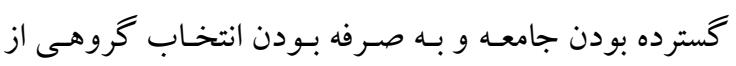

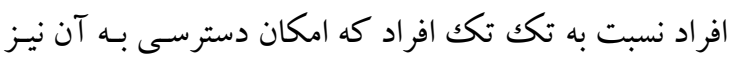

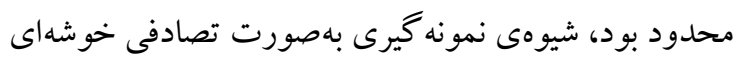

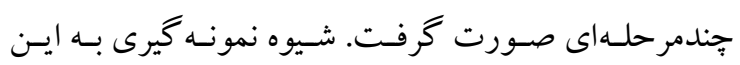

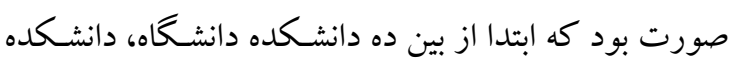

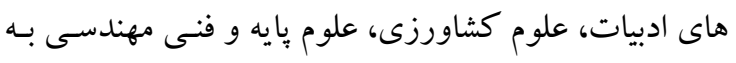

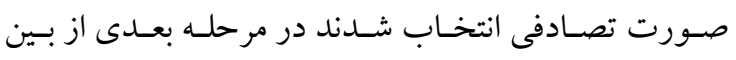
دانشكده هاى مذكور، سه كلاس به طور تصادفى انتخاب و

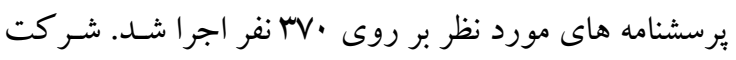

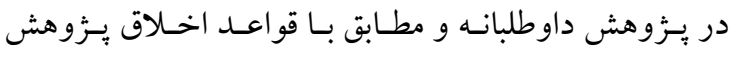

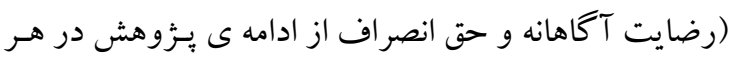

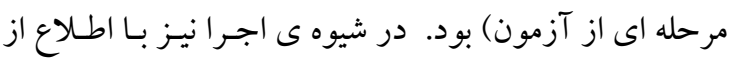

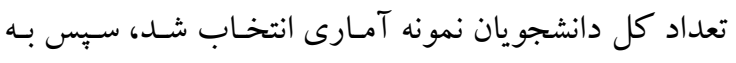
دانشجويان در محل كلاس ها مراجعه و يس از تبيين اهداف

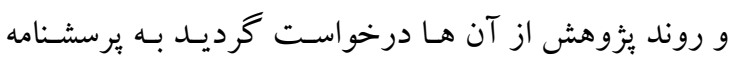

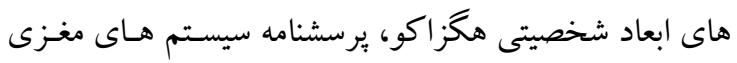

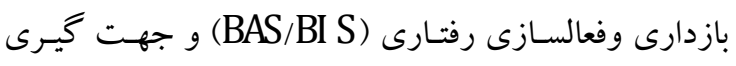
زندگى به صورت انفرادى باسخ دهند و در نهايت داده ها با

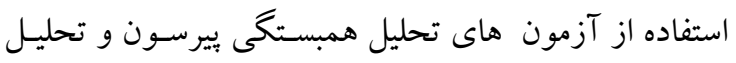

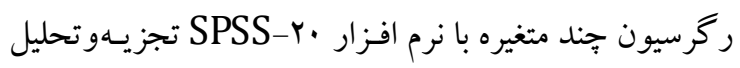
شدند. ميانخين و انحر اف استاندارد سن دانشجويان به ترتيب

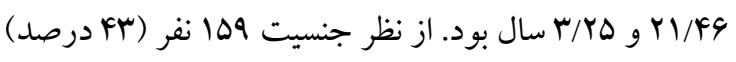

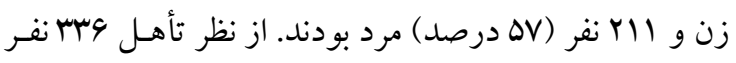

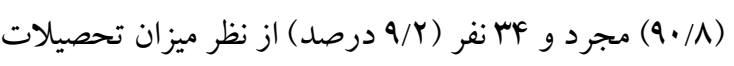

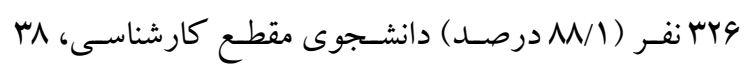

احتمالاً بـا سـهولت بيشـترى شبكههاى اجتمـاعى را توسعه

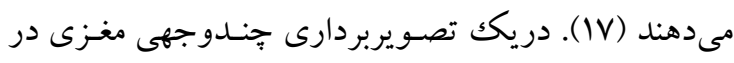

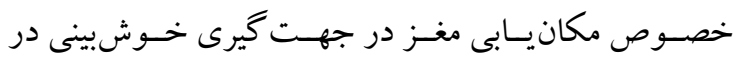

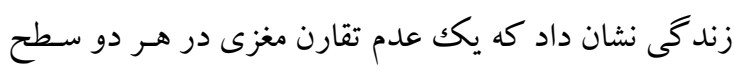

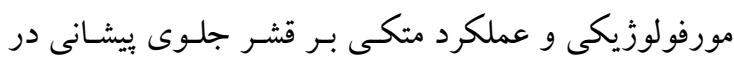
افر اد خوشبين وجود دارد. اين افراد طور معمـول احتمـال

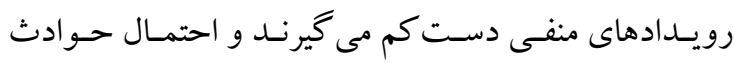

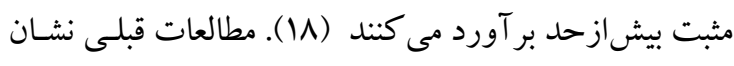

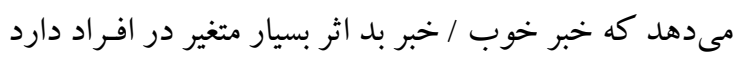

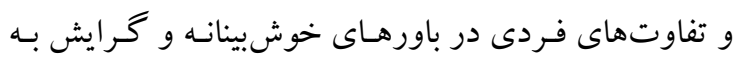

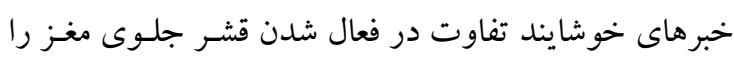

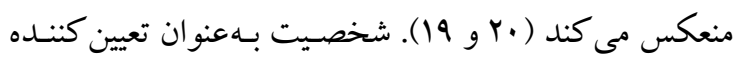

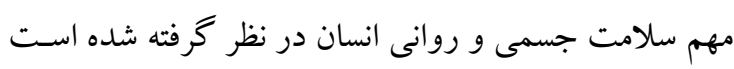

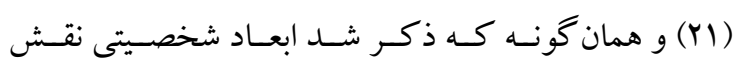
تعيين كنندهاى در خصوصيات رفتارى و روانى افراد دارنه دارد و

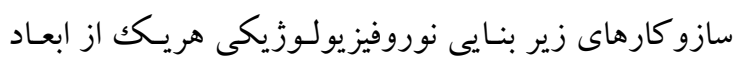
شخصيتى به تفكيك و شناخت آنها بيشتر كمكك مى كند.

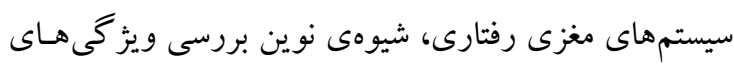

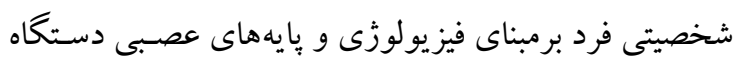

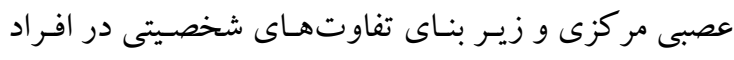

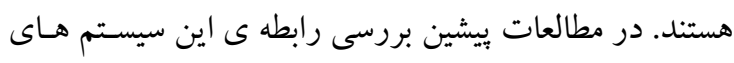

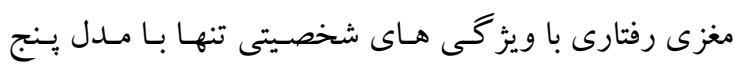

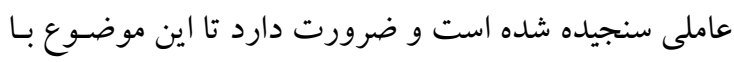

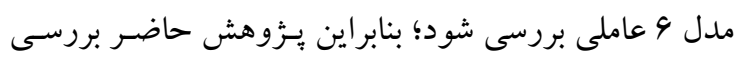

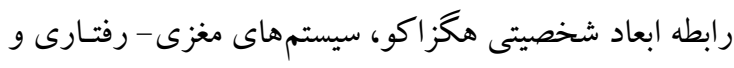

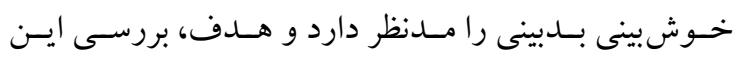

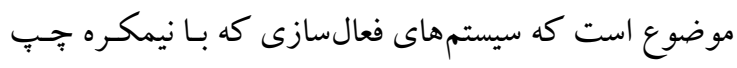

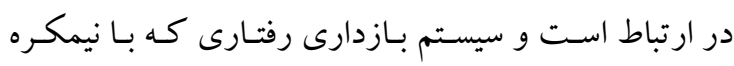

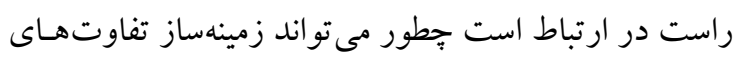
شخصيتى باشد.

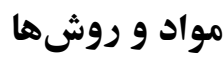


مقياس BI S، مr/· است. در مطالعه آقايوسفى و همكاران (19)، ضريب آلفاى كرونباخ محاسبه شده براى BAS، 191/ .

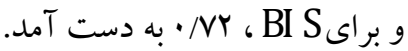
r- آزمون بازنخرى شده جهت گيرى زندگى: ايـن آزمـون،

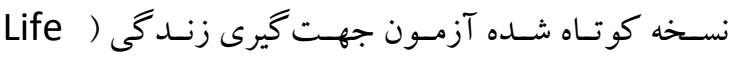
Orientation Test, LOT كه تفاوتهاى فردى در خـوشبينى - بـديينى را مىسـنجد (براى نمونه: در مواقع نامعين، هميشه انتظار بهترين جيز را

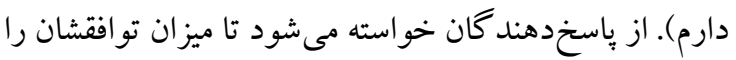

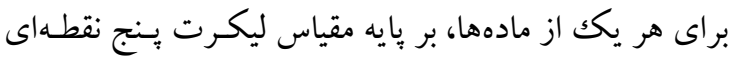

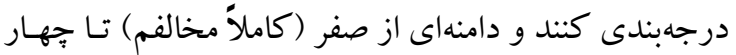
(كـاملاً مـو افقم) دارد. ايـن مقيـاس داراى سـه مـاده دربـاره خوشينى، سه ماده دربـاره بـدبينى و جههار مـاده (إير كنتـهه)

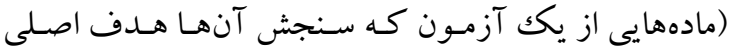

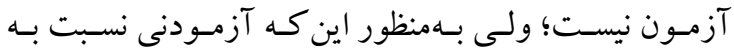
مادههاى اصلى آزمـون حسـاس نشـود بـه كاربرده مى شـوند)

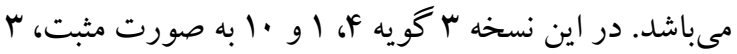

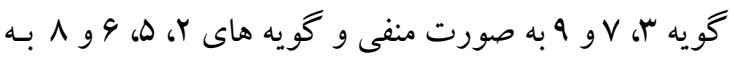

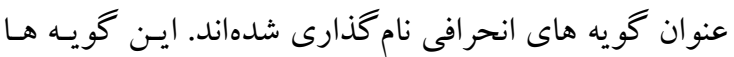
فقط با هدف آزمون دقت مشـاركت كنــــان در باسـخ بـهـ ابزار طراحى شـده اند و در فراينـد نمـره حَذارى آزمـون، محاسبه نميشوند. براى دستيابى به نمرة كلى، لَ سؤال منفى به طور معكوس نمره كذارى مىشوند. در اين مقياس، براى هر يـك از مشـار كت كنند كان، نمرههـا در دامنـه · تـا الب قـرار

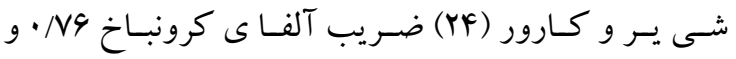

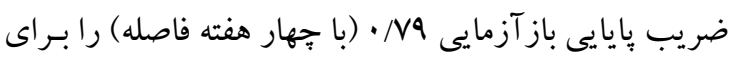

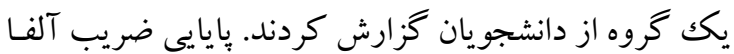

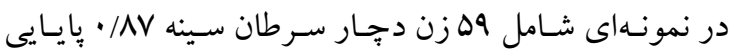

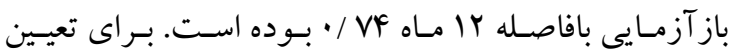

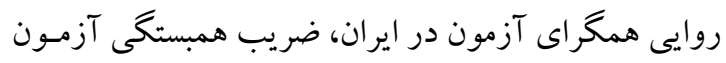

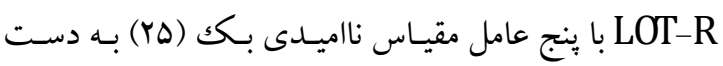

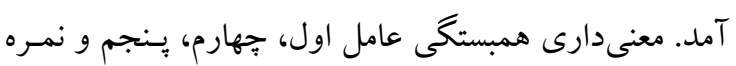

( آ/ • درصد) نفر دانشجوى مقطع كارشناسى ارشد و 9 نفـ دانشجوى مقطع دكترى (1/V درصد) بودند.

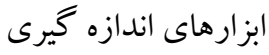

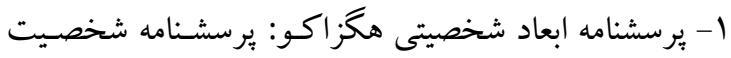
هگز اكو مدلى از ابعاد عاملى شخصيت است كـه داراى ...

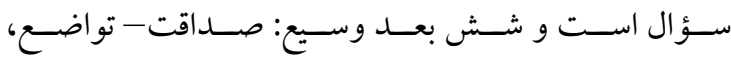

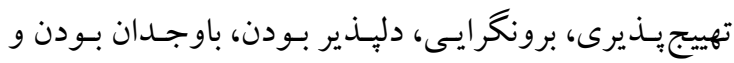

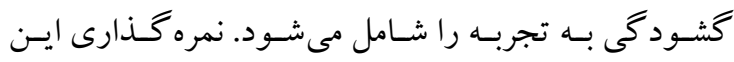
يرسشنامه بهصورت ليكرت با دامنه نمرات بين الى الى هاست است.

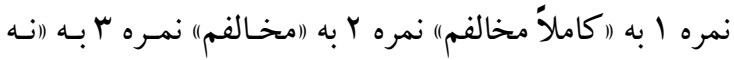

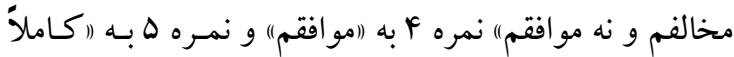
موافقم" اختصاص مى يابد. در مطالعه لى در سـال F...F (Y)،

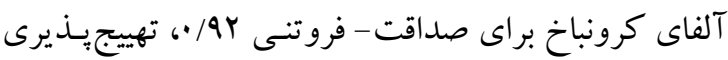

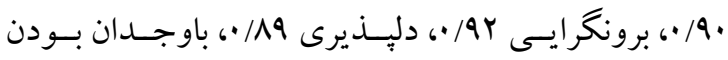

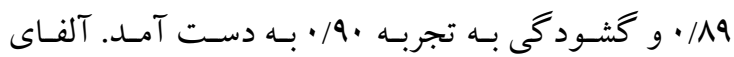
بهدست آمده در جامعـه ايرانى، در مـورد مقيـاس صـداقت-

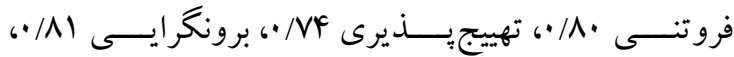

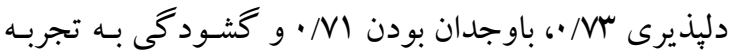

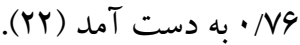
Y- برسشنامه سيستمهاى مغزى بازدارى و فعالسازى رفتارى BAS/BI S) شده است اين مقياس شامل YF برس خش خود گز ارشى است.

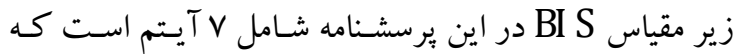

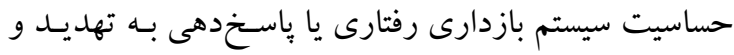
احساس اضطراب هنكام رويـارويى بـا نشـانههاى تهلديـد را اندازه مى گيـرد. زيـر مقيـاس BAS شـامل با آيـم اسـت و حساسيت سيستم فعال ساز رفتارى را اندازه مى گيرد و شامل مئل زيـر مقياسهـاى سـائق، سـر خرمى و وــاداش و تنبيـه اسـت. سؤالات اين مقياس بلصورت هـ درجهاى و بر اساس مقيـاس

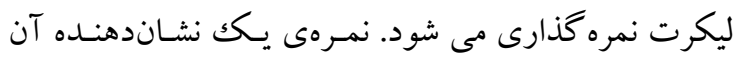

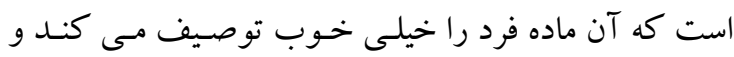

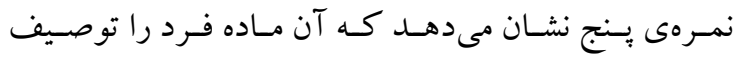

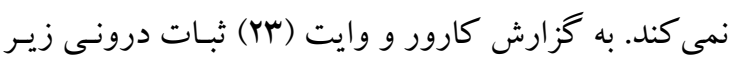




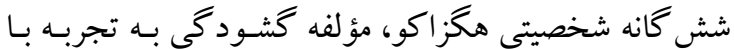
ياداش، خوشبينى، دلِيذيرى و باوجدان بودن رابطه مثبـت و

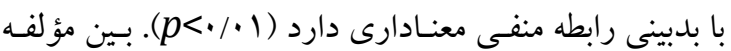

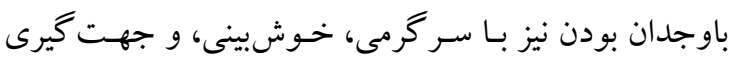

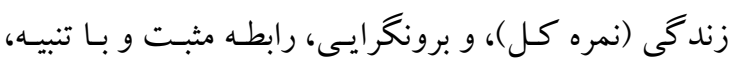

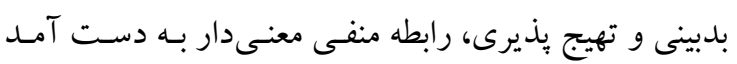

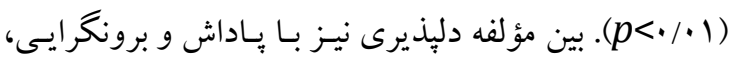

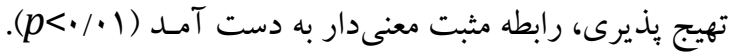

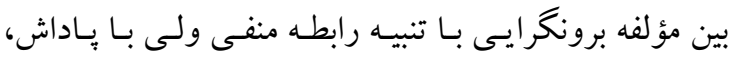

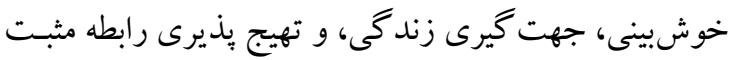

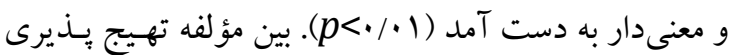

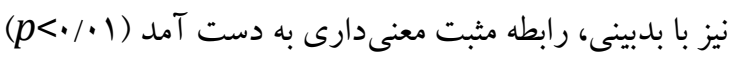

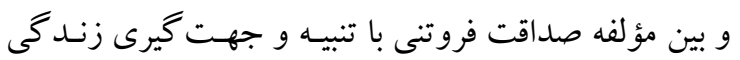
رابطه منفى معنى دار به دست آمد ( (1/•>p). بين مؤلفه تنبيه

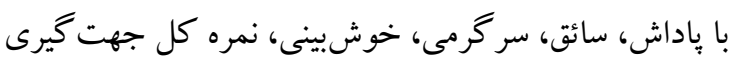

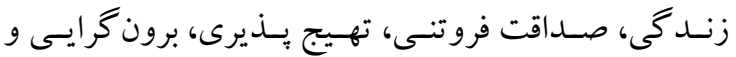

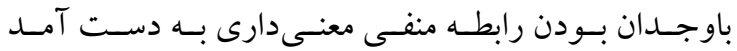

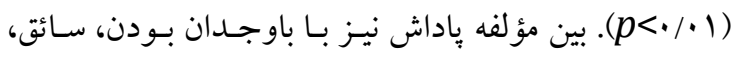

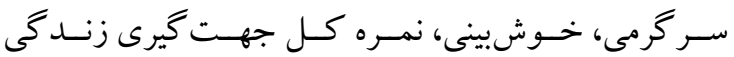

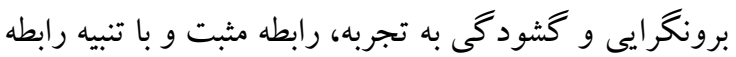

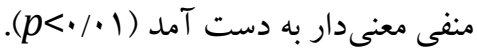

كلى مقيـاس ناميـدى بـك بـا مقيـاس خـوشينى - بـدبينى نشاندهنده اعتبار قابل قبول اين برسشنامه است.

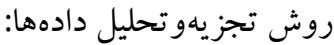

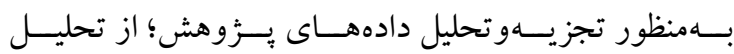
همبستخى بيرسون به منظور تعيين ارتباط بين متغيرهاى ابعـاد

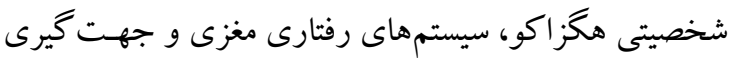

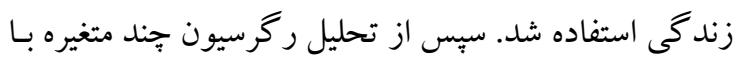
روش همزمـان بـهـ منظور تعيسين نقـش سيستمهاى مغـزى

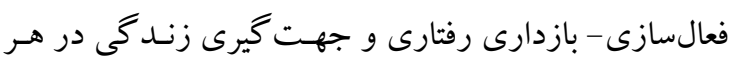

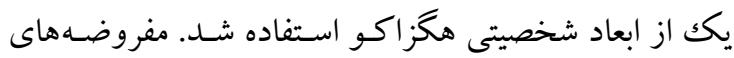

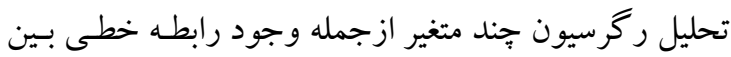

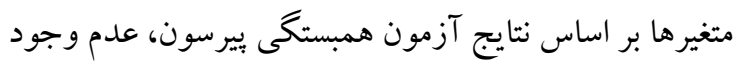

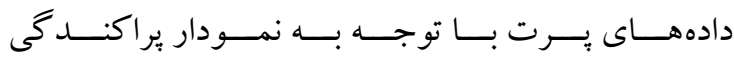

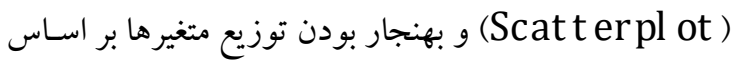

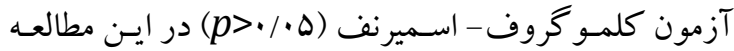
SPSS-Y. رعايت شده است. دادهها با استفاده از نرمافزار

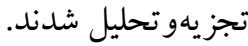

\section{يافتهها} ميانگين و انحر اف استاندارد متغير هاى اندازه گيرى شده در

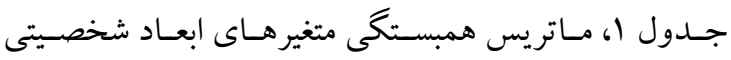

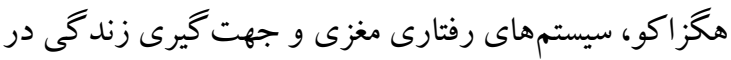
جــول Y. نتـايج جــول ب نشـان مىدهـد كـه از بـين ابعـاد

\begin{tabular}{|c|c|}
\hline $\mathrm{M} \pm \mathrm{SD}$ & متغيرها \\
\hline & سيستمهاى مغزى فعال سازى - بازدارى رفتارى \\
\hline $1.1 . \Delta \pm r / 91$ & تنبيه \\
\hline $1 \cdot / \Delta V \pm r / \Delta \Delta$ & ي باداش \\
\hline$q / \pi q \pm r / r \wedge$ & 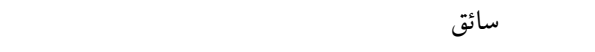 \\
\hline$G / T r \pm r / \mu r$ & 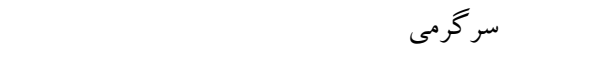 \\
\hline & خ ش سنه \\
\hline & \\
\hline$\Delta / T \Delta \pm T / 4 T$ & 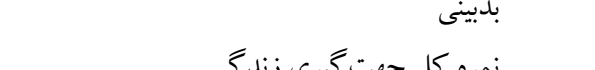 \\
\hline
\end{tabular}

هبله علمى دانشكاه علوم دِزشكى كردستان / دوره بيست و شش / آذر و دى معام 


\section{ابعاد شخصيتى هكزاكو}

\begin{tabular}{|c|c|}
\hline $11 / A V \pm F / \Lambda$. & صداقت - فروتنى \\
\hline$\| / V \Lambda \pm F / \Lambda 1$ & تهييجيذيرى \\
\hline $10 / 9 r \pm F / r$ & برونگر ايى \\
\hline $\mid r / \Delta G \pm F / Y \Lambda$ & دليذيرى \\
\hline$|r / .9 \pm f / q|$ & باوجدان بودن \\
\hline $\mid F / \Lambda 9 \pm F / 90$ & گشود گى به تجربه \\
\hline
\end{tabular}

Note. $\mathrm{M}+\mathrm{SD}=\mathrm{Mean}+\mathrm{Std}$. Deviation

جدول r. ماتريس همبستكى متغيرهاى ابعاد شخصيتى هكزاكو، سيستمهاى رفتارى مغزى و جهت كيرى زندكى

\begin{tabular}{|c|c|c|c|c|c|c|c|c|c|c|c|c|}
\hline Ir & ir & 11 & 1. & 9 & $\wedge$ & $\checkmark$ & 4 & $\Delta$ & F & $r$ & $r$ & متغيرها \\
\hline .1 .9 & $\begin{array}{l}\cdot / 1 r^{* * * *} \\
-\end{array}$ & $-\cdot / \cdot r$ & $\begin{array}{l}\cdot / 1 V^{* * * *} \\
-\end{array}$ & .1 .9 & $\begin{array}{l}\cdot / 19^{* * * *} \\
-\end{array}$ & $\begin{array}{l}\cdot / Y^{* * * *} \\
-\end{array}$ & $\cdot / \cdot V$ & $\begin{array}{l}\cdot / \Lambda^{* * * *} \\
-\end{array}$ & $\begin{array}{l}\cdot / 1 r^{* * * *} \\
-\end{array}$ & $\begin{array}{l}\cdot / / F^{* * * *} \\
-\end{array}$ & $-\cdot / 19^{* * *}$ & 1. تنبيه \\
\hline$\cdot / 10^{* * * *}$ & .1 .9 & $\cdot / \Lambda^{* * * *}$ & $\cdot / \mathrm{N}^{* * *}$ & $\cdot / \cdot 1$ & $\% r$ & $\cdot / Y)^{\text {**** }}$ &.$/ . F$ & $\cdot / r^{* * * * *}$ & $\cdot / q^{* * * *}$ & $\cdot / 4 \cdot{ }^{* * * * *}$ & 1 & r. باداش \\
\hline$\cdot / \cdot r$ & $\cdot / \cdot v$ &.$/ \cdot 1$ & -.1 .9 &.$- / \cdot \Delta$ & -.1 .4 & $\cdot / r \Delta^{* * * *}$ &.$/ .4$ & $\cdot / \Lambda^{* * * *}$ & $\cdot / \mathscr{A v} *$ & 1 & & r. سائق \\
\hline$\cdot / 1$ & $\cdot / 1 Q^{* * * * * *}$ &.$/ . r$ &.$/ . r$ & $-\cdot / \cdot f$ &.$/ .4$ & $\cdot / \cdot \Lambda$ & .1 .9 & $\cdot / 11^{*}$ & 1 & & & F. سر گرمى \\
\hline$\cdot / r^{* * * * *}$ & $\cdot / 19^{* * *}$ &.$/ \cdot 1$ & $\cdot / / F^{* * * * * *}$ & $-\cdot / \cdot V$ & .1 .9 & $\cdot / \wedge 9^{* * * *}$ & $-\cdot /\left.Y\right|^{* * * *}$ & 1 & & & & ه. خوشبينى \\
\hline $\begin{array}{l}\cdot / Y F^{* * * * *} \\
-\end{array}$ & 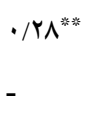 & .1 .9 & $-\cdot / \cdot r$ & $\cdot / r \cdot{ }^{* * * *}$ & $\cdot / \cdot 1$ & 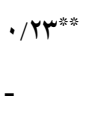 & 1 & & & & & 9. بدبينى \\
\hline $.1 \cdot 9$ & • & $\cdot / \cdot r$ & $\cdot /\left.\right|^{* * * *}$ & $-\cdot / \cdot r$ & $\begin{array}{l}\cdot / 1 r^{* * * * *} \\
-\end{array}$ & 1 & & & & & & 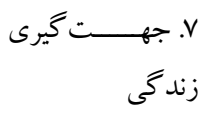 \\
\hline$\cdot / \cdot r$ &.$/ \cdot 1$ &.$/ \cdot 1$ &.$/ \cdot r$ & .1 .9 & 1 & & & & & & & 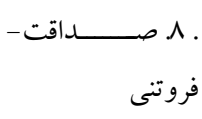 \\
\hline $.1 \cdot 9$ & $\begin{array}{l}\cdot / 1^{* * *} \\
-\end{array}$ & $\cdot / 19^{* * * *}$ & $\cdot / V^{* * *}$ & 1 & & & & & & & & 9. تهييج يذيرى \\
\hline$-\cdot / \cdot F$ & $\cdot / 19^{\text {******** }}$ & 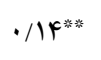 & 1 & & & & & & & & & • ا. برونگر ايى \\
\hline$\cdot / 1 V^{* * * *}$ &.$/ \cdot r$ & 1 & & & & & & & & & & 11. دلذيرى \\
\hline$\cdot / 1$ * $^{* * * *}$ & 1 & & & & & & & & & & & זا. זا. باوجدان بودن \\
\hline & & & & & & & & & & & & تجربه \\
\hline
\end{tabular}

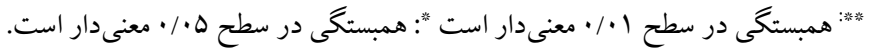

باوجدان بودن و 11 درصد بعد گشودگى به تجربـه رادر ابعـاد شخصيتى هكز اكو تبيين مى كنند. درمجموع مؤلفههاى سيستم

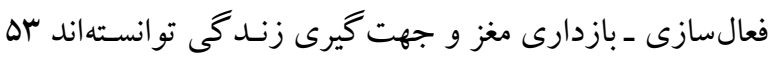
درصد ابعاد شخصيتى هكز اكو را تبيين كنند. نسبت F هم نشان مى دهد كـه ييشبينى تمـام ابعـاد شخصـيتى هخًزاكو توسط مؤلفه هاى سيستم فعالسـازى - بـازدارى مغـز و جهت گيرى زندگى معنادار است (ه •/ •>p)؛ يعنى رابطه بـين

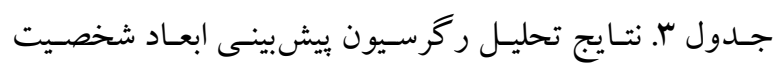
توســط مؤلفـهـهاى سيسـتم فعالســازى -بــازدارى مغــز و و جهت گيرى زندگى (خوش بينى بدبينى)

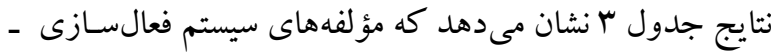

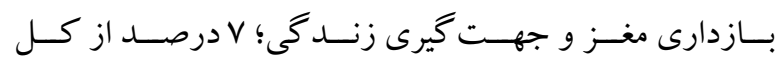
واريانس هاى بعد صداقت - فروتنى، 9 درصد بعد تهيج يذيرى،

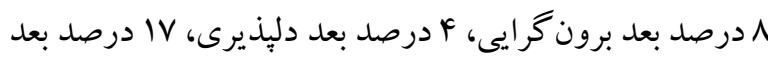




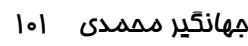

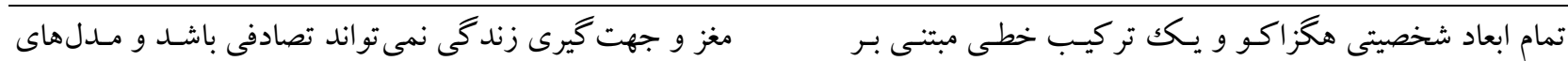

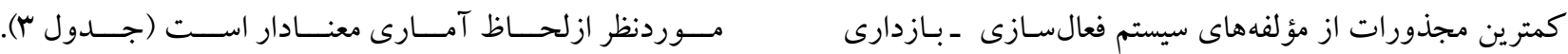

جدول Гا. نتايج تحليل ركرسيون ييشينى ابعاد شخصيت توسط مؤلفههاى سيستم فعال سازى ـ بازدارى مغز و جهت كيرى زندكى (خوشينى بدبينى)

\begin{tabular}{|c|c|c|c|c|c|c|c|c|c|c|c|c|c|}
\hline $\mathbf{T}$ & Beta & $\mathbf{F}$ & $\begin{array}{r}\text { Adj. } \\
\mathbf{R}^{2}\end{array}$ & $\begin{array}{r}\mathbf{R} \\
\left(\mathbf{R}^{2}\right)\end{array}$ & متيشيين & ملغير & $\mathbf{T}$ & Beta & $\mathbf{F}$ & $\begin{array}{r}\text { Adj. } \\
\mathbf{R}^{2}\end{array}$ & $\begin{array}{r}\mathbf{R} \\
\left(\mathbf{R}^{2}\right)\end{array}$ & متيشبين & ملاكت \\
\hline & & 「/৭४** & $\cdot / \cdot r$ & $\begin{array}{r}(\cdot / \cdot \varphi) \\
.|r|\end{array}$ & & دليذيرى & & & $\Delta / . . * * * *$ & .1 .9 & $\begin{array}{l}\cdot / \cdot Y \\
(\cdot / r Y)\end{array}$ & & فروتنى \\
\hline - /191 & .1 .1 & & & & تنبيه & & $\begin{array}{r}\varphi / T \Delta^{* * *} \\
-\end{array}$ & $\begin{array}{r}\cdot / \pi r \\
-\end{array}$ & & & & تنبيه & \\
\hline$\Gamma / \varphi \gamma^{* * *}$ & $\cdot|r|$ & & & & ياداش & & $1 / 9 r^{*}$ & .111 & & & & پֶاداش & \\
\hline.$/ 4 q$ & $\cdot 1 \cdot r$ & & & & سائق & & $\begin{array}{r}r / \cdot r^{*} \\
-\end{array}$ &.$/ 1 T$ & & & & سائق & \\
\hline $1 / \cdot 0$ & .1 .9 & & & & سركرمى & & $\cdot / A \Delta$ & $.1 \cdot 0$ & & & & سركرمى & \\
\hline$\cdot / 4 \Delta$ & $.1 . r$ & & & & خوشيينى & & $\begin{array}{r}r / A r^{* * *} \\
-\end{array}$ & $\begin{array}{r}.110 \\
-\end{array}$ & & & & خوشينى & \\
\hline $1 / \pi$ & $\cdot 1 \cdot v$ & & & & بدينى & & $r / Y r^{* * *}$ &.$/ 14$ & & & & بديينى & \\
\hline & & $\mid r / \Lambda^{* * *}$ & .119 & $\begin{array}{l}(\cdot / / Y) \\
\cdot / q Y\end{array}$ & & بواوجدان & & & $\varphi / l \mu^{* * * *}$ & $.1 . \varphi$ & $\begin{array}{r}(.1 .9) \\
. / 4 \Delta\end{array}$ & & تهيري تيــــ \\
\hline$-\cdot / A \Delta$ & & & & & تنبيه & & $r / .1^{*}$ &.$/ 11$ & & & & تنبيه & \\
\hline$-\cdot|\Delta|$ & $-\cdot / \cdot r$ & & & & پاداش & & $-1 / v 9$ & - & & & & ֶֶاداش & \\
\hline.$- / 99$ & .1 .0 & & & & سائق & & $-\cdot / 4$. & $\begin{array}{r}.1 . r \\
-\end{array}$ & & & & سائق & \\
\hline$\Gamma / \cdot \gamma^{* * *}$ &.$/ 1 \gamma$ & & & & سركرمى & & -.1 .9 & $\begin{array}{r}* \cdot 00 \\
-\end{array}$ & & & & سركرمى & \\
\hline$\Delta / \cdot 1^{* * * *}$ &.$/ 48$ & & & & خوشيينى & & $1 / 0$. & $\cdot / \cdot 1$ & & & & خوشبينى & \\
\hline$-Y / \cdot 1^{* * *}$ &.$- / T \varphi$ & & & & بدينى & & $\Gamma / \Gamma \Gamma^{* * * *}$ &.$/ 1 Y$ & & & & بديينى & \\
\hline & & $\mathrm{V} / 99^{* * *}$ & .1 .9 & $\begin{array}{c}(\cdot / 11) \\
. / \pi T\end{array}$ & & به تجربه & & & $\Delta / \varphi^{\prime * * *}$ & .1 .9 & $\begin{array}{r}(\cdot / \cdot 1) \\
\cdot / \% 1\end{array}$ & & برونترايى \\
\hline 11.9 & $.1 \cdot 0$ & & & & تنبيه & & $\begin{array}{r}\Gamma / \varphi \Delta^{* * *} \\
-\end{array}$ & $\begin{array}{r}\cdot 111 \\
-\end{array}$ & & & & تنبيه & \\
\hline$r / T \Lambda^{*}$ &.$/ 1 \pi$ & & & & يّاداش & & $\varphi / \cdot \Lambda^{* * *}$ & $\cdot \mid \pi r$ & & & & پِاداش & \\
\hline$-1 / 8 Y$ & $-\cdot / 1$ & & & & سائق & & $-1 / A r$ & $\begin{array}{r}\cdot 111 \\
-\end{array}$ & & & & سائق & \\
\hline $1 / P V$ & $\cdot 1 \cdot 1$ & & & & سركرمى & &.$- / 10$ & $\begin{array}{r}.109 \\
-\end{array}$ & & & & سركرمى & \\
\hline$\Gamma / .^{* * *}$ & .119 & & & & خوشينى & & $1 / v \Delta$ & .1 .9 & & & & خوشبينى & \\
\hline$-\varphi / \cdot \varphi^{* * *}$ & $-\cdot / r$ & & & & بدينى & &.$/ v r$ & $\cdot 1 \cdot 4$ & & & & بديينى & \\
\hline
\end{tabular}

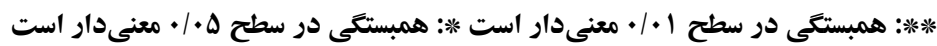

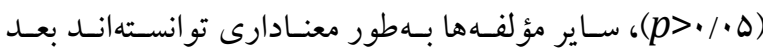

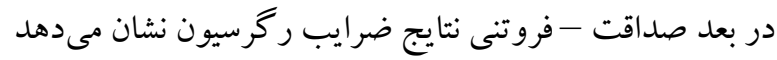

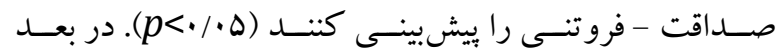

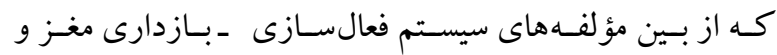

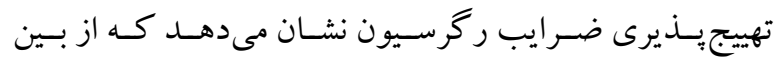

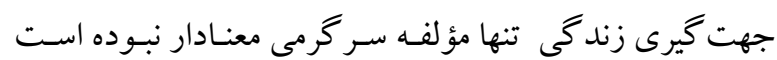

هبمله علمى دانشكاه علوه يِشكى كردستان / دوره بيست و شش / آذر و دى م.ع|| 


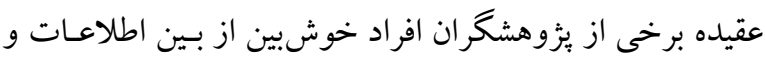

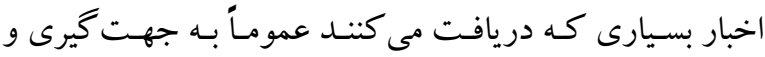
انتخاب اطلاعات و خبرهـاى خـوب گُرايش دارنـد؛ امـا افراد

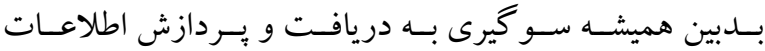
ناخوشايند دارند و انتظار دارند كارها در جهت نامطلوب يسيش

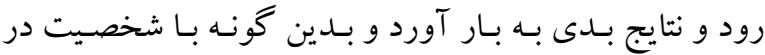

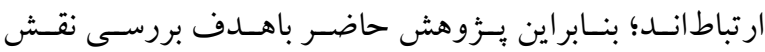

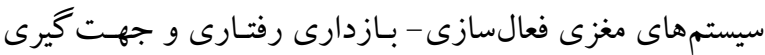
زند گى در ابعاد شخصيتى هكزاكو انجام گرفت.

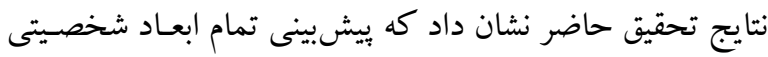
هكزاكو توسط مؤلفه هاى سيستم مغزى فعالسـازى ـــازدارى

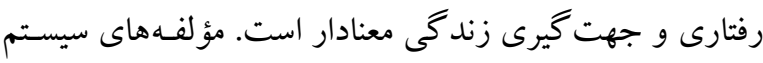

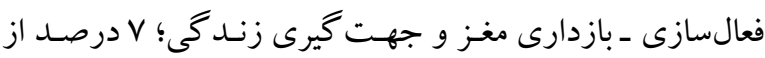

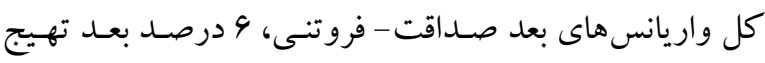

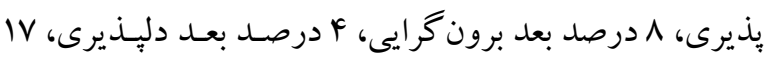

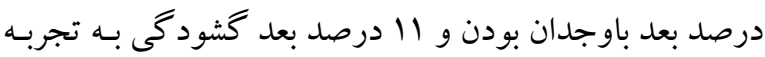

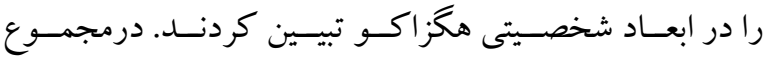

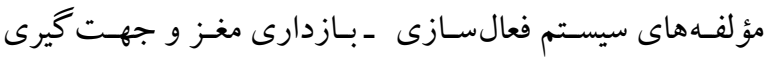

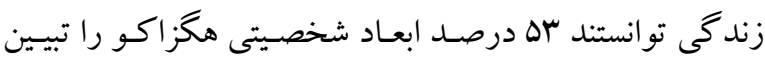

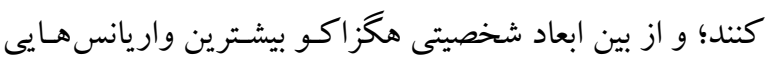
كه توسط متغيرهاى سيستم هـاى مغزى فعـال سـازى -بـازدارى

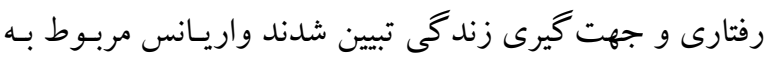

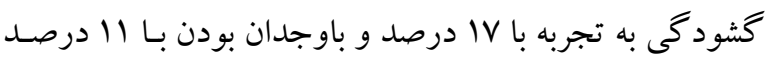
از بين مؤلفههاى سيستمهاى مغزى فعال سازى-بازدارى رفتارى

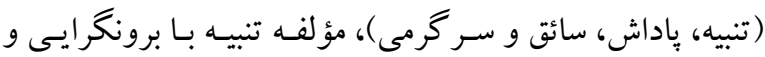
باوجدان بودن رابطه منفى و مؤلفه پِاداش با برونخر ايى دليذيرى و با وجدان بودن و سر گرمى با وجدان بودن رابطه مثبت داشت.

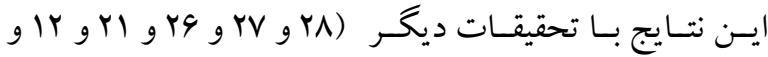

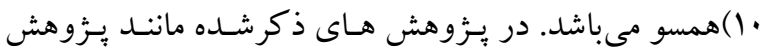
حاضـر، سيسـتمهاى مغـزى -رفتـارى زمينهسـاز تفاوتهـاى شخصيتى اسـت؛ و سيستمهـاى سيستمهاى مغـزى فعالسـازى

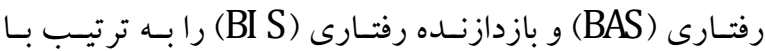

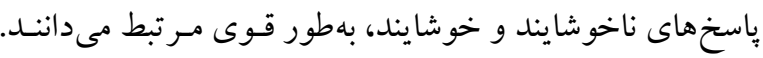

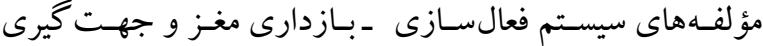

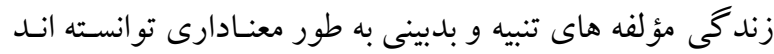

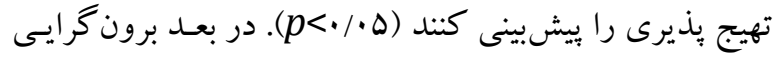

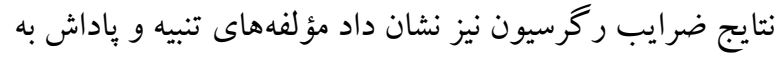

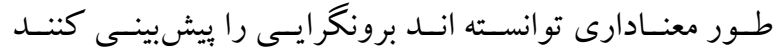

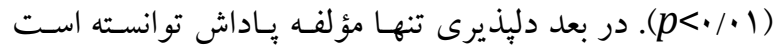

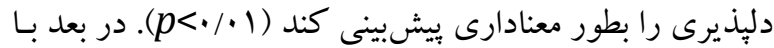
وجدان بودن مؤلفههاى سر گرمى، خوشبينى و بدبينى

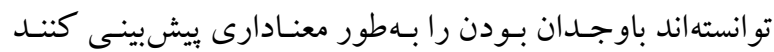

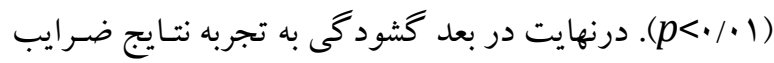

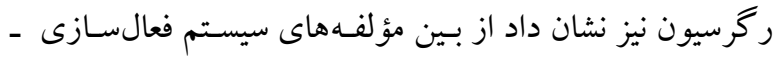

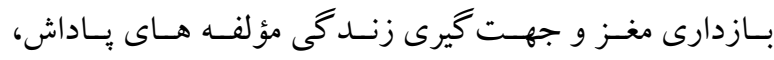

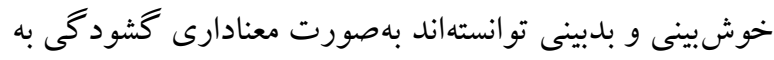

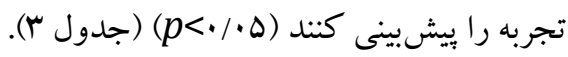
روانشناسـان شخصـيت در حـال نزديـك شـــن بـه يـك وفـاق

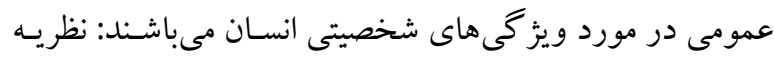

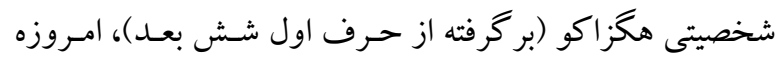

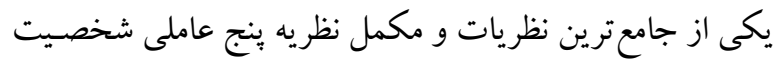
در عرصه مطالعه شخصـيت اسـت كـه متشـكل از شـش عامـل

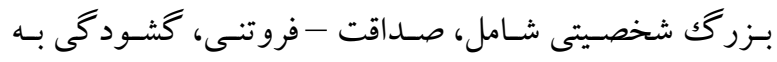

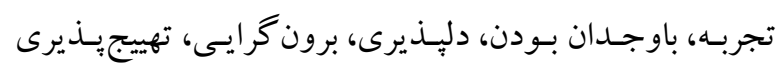

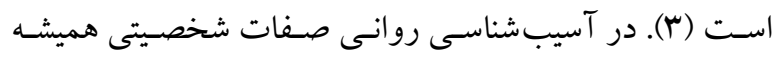
نقش مهمى در بيدايش بيمارى هاى جسمى و روانى مـزمن دارد

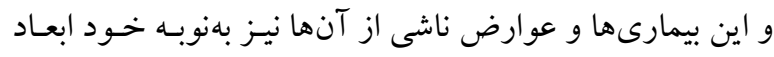
مختلف شخصيت بيمـار را تحت تأثير قرار مىدهنـد (Vو و). عوامل مختلفى در تعيين اين تفاوتهاى فردى دخيل هستند كه موجب عادات رفتارى و خلقىوخوهاى متفاوت در افراد مى شود كه آنها را مستعد سلامت و بيمارى جسمى و روانى مى سـازد. يكى از اين تعيين كندههاى مهم سيستمهاى مغزى و رفتارى است. ميزان و غلبه اين سيستمها در افراد مختلف، متفاوت است و اين امر زيربناى تفاوتهاى شخصيتى در افراد است. از طرفى

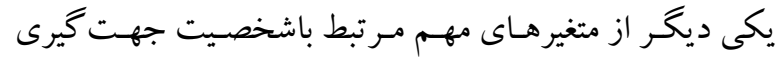
زندگى و تفاوتهاى فردى در خـوشيينى و بـدبينى اسـت. بـه 
مرتبط با بازدارى و اجتناب رفتارى و همجنـين ايجـاد احسـاس اضطر اب و بر انگيختخى فعال مىشود. در تبيين يافته ها مىتوان كفت كه سيستمهاى مغزى فعالسازى رفتارى (BAS) و بازدازنـده رفتـارى (BI S) در مغـز بهصورت نيمكرهاى جانبى يـا طرفى شـدهاند؛ سيسـتم مغـزى فعالسـازى

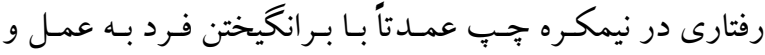
نزديكك شدن به محـرك مثبـت / جـذاب مـر تبط اسـت و رفتـار جستجوى ياداش، احساس غرور و اميد به ياداش را بهرغم خطر يا تهديد موجود فعال مىسازد كه نتيجه آن مى تواند هيجانهاى مثبت و معاشرتى بودن و برونگر ايسى باشـد. درحالى كـه سيستم مغزى بازدارى رفتارى در نيمكره راسـت منجـر بـه اضـطراب، بـازدارى و اجتنـاب فعـل يـذير در ياسـخ بـه نشـانه هاى تنبيسه و محر ككهـاى جديــ مى شـود و در اجتنـاب از خطرات و مهـار اعمالى كه منجر به بيامدهاى دردناكك مى گردد، دخيـل اسـت؛ كه اين سيستم نيز با تهيج و تحريككيذيرى و درونگرايى مرتبط است (Y) (I). موارد يادشده نشان مىدهد كه درواقع اعمال عـالى

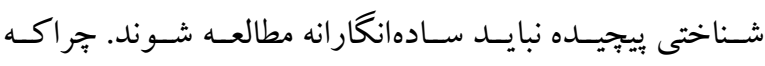
تفاوتهاى مورفولوزيكى و فاكتورهاى روانى و محيطى بسـيار زيـادى مى توانتــل بـهـور مسـتقيم و غيرمسـتقيم ايسن اعمـال را تحت الشعاع قرار دهند. براى مثال، در مطالعـه لويتـا (بT) روى حيوانات نشان داد كه هيبو كامبٍ ممكن اسـت نقـش مهمسى در اضطراب بهعنـوان بخشى از سيستم بازدارنـده رفتـارى (BI S) بازى كنـد، واكـنش بـه تهلديـد و تنبيـه را ميـانجيخرى كرده و مى تو اند ياسخ فرد بـه سـرنخهاى مـر تبط بـا اضـطر اب در يـك محيط معين را بيشبينى كند. نتايج مطالعـه آنـان نشـان داد كـه حجم هيبو كامبٍ به ابعاد عاطفى و شناختى اضطر اب نمايه شـده توسط حساسيت بـه تنبيـه مـرتبط اسـت و از ايـن ايـده حمايـت مى كند كه تفاوتهاى مورفولوزيكى در تشكيلات هييو كامـبِ ممكن است با مشـار كتهاى بـازدارى رفتـارى بـه اضـطراب و تهيج يذيرى مرتبط باشد. نتايج آنان نشاندهنده رابطه مثبت بين بازدارى رفتارى و حجم هيبو كامِّ راست بـود. همجنــين نشـان داد كه تغيير يا تنوع ساختارى بر حجم هييو كامب تأثير داشته و

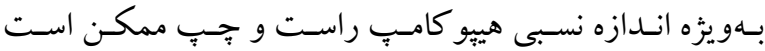
نشاندهنده آمادكى يا نقش در ميانجيخرى اضطراب مـرتبط بـا

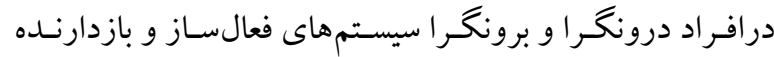
بهصورت متفاوت عمل مى كند كه تفاوت سطوح برانگيختخى

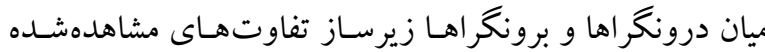
ميان اين گروه در بِاسخ هايشان به محيط و عملكرد در تكـاليف است. تـامير، رابينسـون و كلـور (Y^) در جنـــين بررسى نشـان دادنـــ همخــوانى ميـان سيسـتم مغـزى ـرفتــارى و اطلاعـات محر ككهاى بيرونى و تأثير آنها بر عملكرد اهميت دارد، افراد

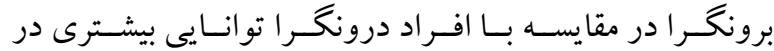
كد گذارى ياداش هاى محيطى دارنـــ و ايـن همخـوانى سيستم انخگيزشى درونى و علائسم بيرونسى بـاداش مى توانــ بـر شـناخت

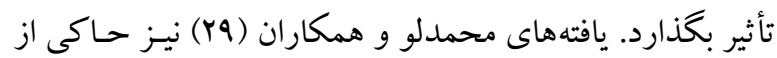
اين بود كه فعاليت بيشازاندازه سيستم بازدارى، منجر به صفات شخصيتى مانند تهيج بذيرى و رفتارهاى مر تبط با اضطراب مثل

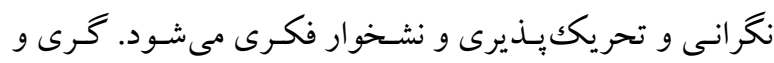
همكاران (A) مطرح مى كنند كه ميز ان و غلبه ايسن سيستمها در افراد مختلـف، متفـاوت اسـت و ايـن امـر زيربنـاى تفاوتهـاى شخصيتى در افراد است. جاسكو (·r) طى دو مطالعه، نشان داد كه سيستم بـازدارى رفتـارى مى توانـد رفتـار را درزمينـه اتخـاذ تصميم تنظيم كند. سوترلين و همكاران ( اس) اشاره كردنـد كـه عملكردهاى اجرايى و اجزاى اساسى آنها مانند رفتار مبتنى بـر هـدف، حافظـه فعـال و ياسـخ هيجـانى يـا عـاطفى تنظيمشـده، موجب استفاده شديد از فر آيندهاى بازدارنـده نشـات كرفتـه از قشر بيش بيشانى مى شود. در تضاد با بازدارندگى رفتارى نمايسه شـده بـا مقيـاس سيسـتمهاى مغـزى بازدازنــده رفتـارى (BI S)، كـاهى سيستم هاى مغـزى فعالسـازى رفتـارى (BAS) نيـاز بـه

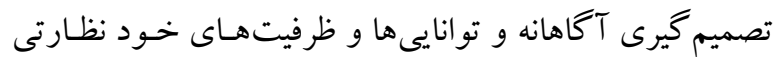
منعكس در تأخير لذت، برنامههاى عمليـاتى متـوالى و يـردازش مرتبه بالاتر، است. برون گر ايى برحسب تفاوتهـاى فردى در

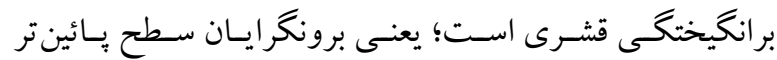
بر انكيختخى قشرى را نسبت به درون گرايان دارند (Y^). سيستم

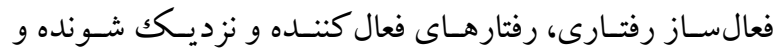
احساس برانگيختخى و اميد و خوشايندى را بيشـتر مى كنـد. در مقابل سيستم بازدارى رفتارى در مواجه با علائم مربوط به تنبيـه و فقدان باداش و محر ككهاى جديد در جهت ايجاد ياسـخهاى 
افراد تيب شخصيتى B خـوشبين تر از افراد تيسب شخصيتى A

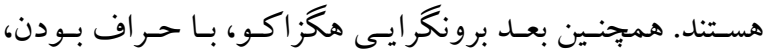
اجتماعى بودن، سرخوشى، نيـاز بـه محر كك و ظرفيـت تجربـه عو اطف مثبت و خوشينى مشخص مى شود (r) و بـايين بـودن اين بعد بـا كمرويس، انفعـال، كم تحركى، عـدم ابراز وجـود،

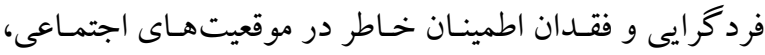
تودار و ساكت بـودن و بـدبينى (Yr) همراه اسـت. برونخرايسى

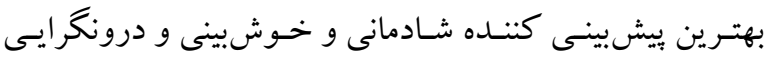
بهترين ييشينى كننده عواطف منفى و بدينى است.

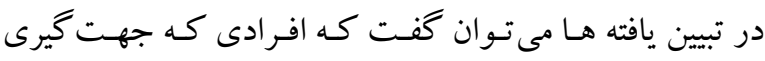
زندگى خوش بين بيشترى در زنـدگى تجربـه مى كنتـد ازلحساظ

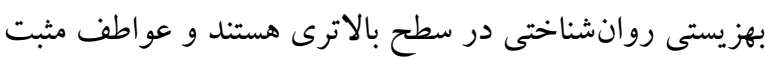
(شادى، سرزند گى، وظيفهشناسى و گشود گى به تجربه) بيشتر و

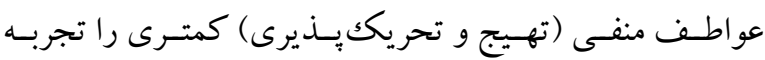

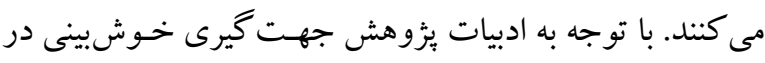
زندگى باعث مى شود فرد احسـاس كار آمـدى و كنتـرل، خـود

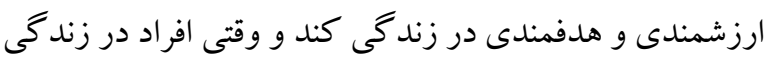

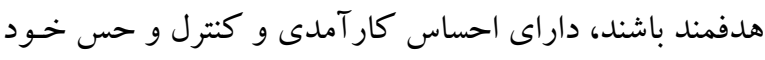
ارزشمندى داشته باشند در اين صورت قادرند در رويارويى بـا

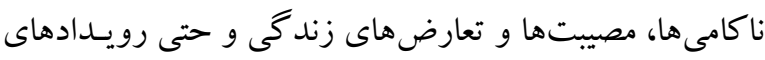
مثبت، ييشرفت ها و مسئوليت و صداقت و وظيفهشناسى بيشتر به تلاش ادامه دهند و براى دستيابى به موفقيت تـلاش كنتـد. ايـن

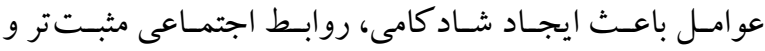

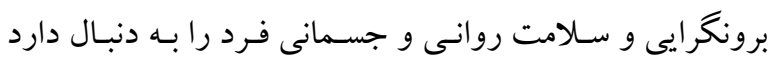

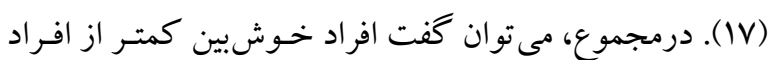

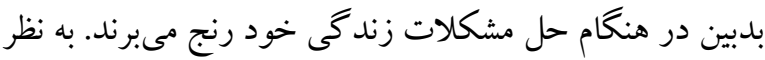

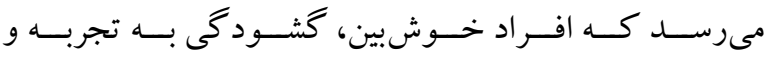
مسئوليت بِذيرى بيشترى در هنگحام رويـارويى بـا مشـكل انجـام

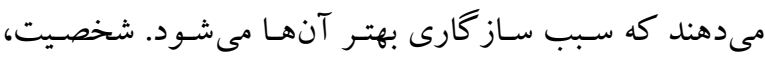

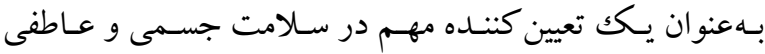

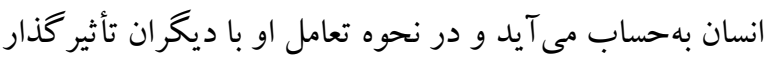

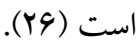
اين مطالعه داراى مححدوديت هايى بود كه مى تـوان بـه محـدود

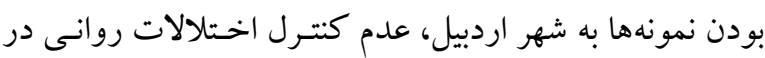

سيستمهاى مغزى بازدارنده رفتـارى (BI S) بـوده و حـامى ايـن

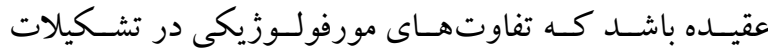

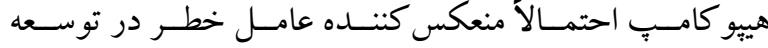

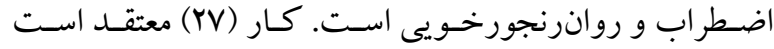
سيستم هاى مغزى ــرفتارى يكى از مهم تـرين عوامـل درونزاد

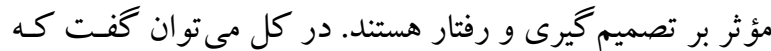
افرادى كه سيستم بـازدارى مغزيى در آنهـا غلبه دارد، بيشتر

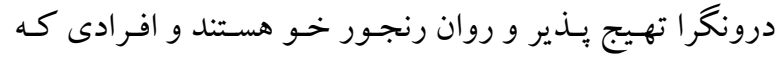
سيستم فعالسـازى مغـزى در آنهـا غلبـه دارد ،بيشـتر افـراد برونگرا، تجربه يذير هستند معاشرتى و خوشبين هستند.

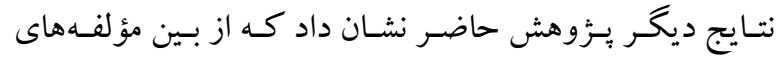

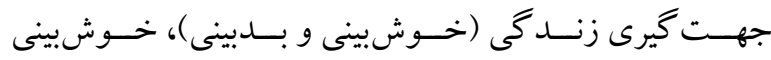

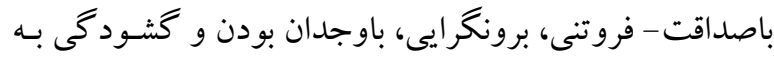

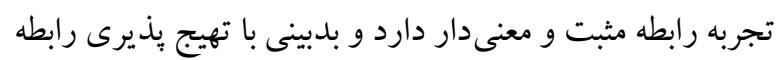

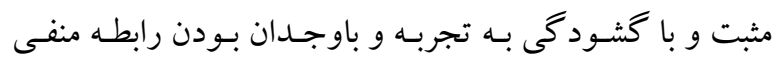

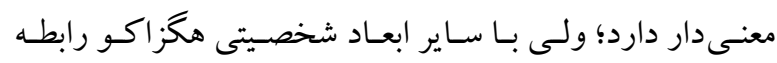
معنى دارى نداشتند. نتايج با يافتههاى شـريفى و سعيدى (IV)؛

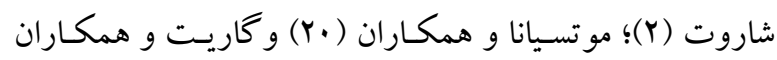

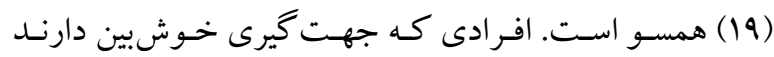

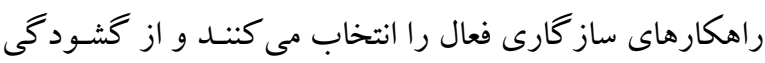

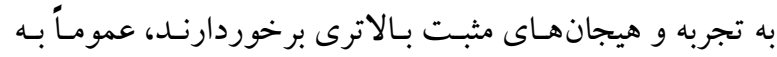

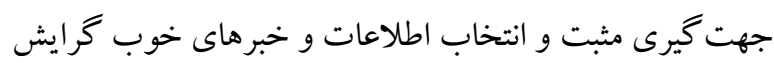

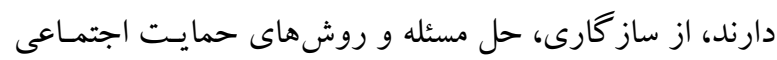

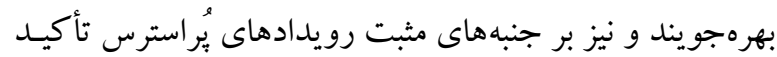

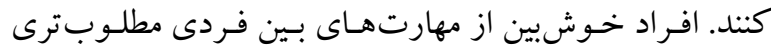

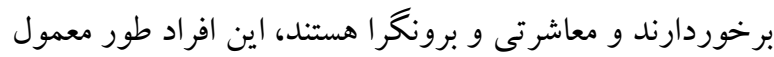

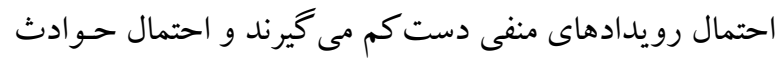
مثبت بيشازحد بر آورد مى كنند. نتايج مطالعه جهانبين (بساك)

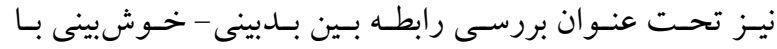

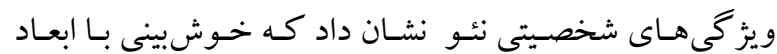
شخصيتى برونگرا و باوجدان بودن و گشودگى به تجربه رابطه مثبت دارد و بدبينى با روان رنجور خـويى و بىثبـاتى هيجانى

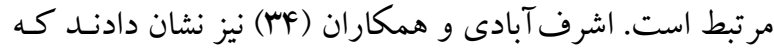

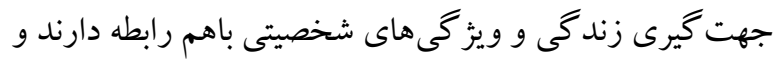




$$
\begin{aligned}
& \text { آزمودنى ها و استفاده صرف از يرسشنامه به عنوان ابزار سـنجش واريانس مربوط به ابعاد گشودگى بـه تجربـه و باوجـدان بـودن } \\
& \text { اشـاره كـرد؛ لـذا بيشـنهاد مسىشـود كـه مطالعـاتى مشـابه روى بود. درمجموع مؤلفه هاى سيستم فعالسـازى - بـازدارى مغـز و }
\end{aligned}
$$

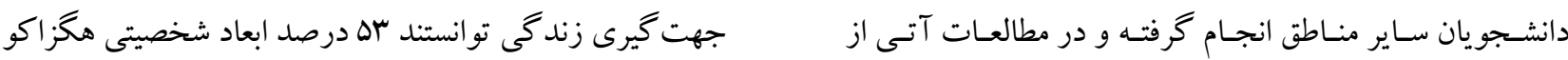

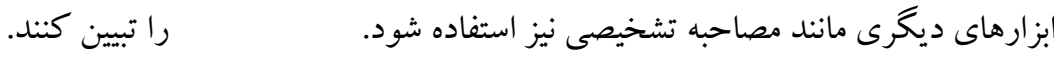

$$
\begin{aligned}
& \text { تشكر و قدردانى } \\
& \text { نويسند أن اين مقاله از شر كت كنند كان در اين يثوهش كمال } \\
& \text { قدردانى را دارند. هيج كدام از نويسندكان اين مطالعه، افراد و } \\
& \text { يا دستگاهها تعارض منافعى براى انتشار اين مقاله ندارند. }
\end{aligned}
$$

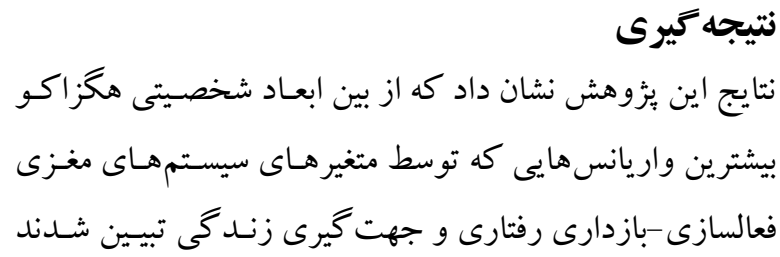

1.Jovanović D, Lipovac K, Stanojević P, Stanojević D. The effects of personality traits on drivingrelated anger and aggressive behaviour in traffic among Serbian drivers. Transp Res Part F Traffic Psychol Behav. 2011; 14 (1): 43-53.

2.Sharot T, Garrett N. Forming beliefs: Why valence matters. Trends Cogn Sci. 2016; 20 (1): 25-33.

3.Lee K, Ashton MC. Psychometric properties of the HEXACO personality inventory. Multivariate Behav Res . 2004; 39 (2): 329-58.

4.Ashton MC, Lee K, De Vries RE. The HEXACO Honesty-Humility, Agreeableness, and Emotionality factors: A review of research and theory. Pers Soc Psychol Rev. 2014; 18 (2): 139-52.

5. Palahang H, Nikfarjam M, Salahian A. The efficacy of emotionality factor of HEXACO-PI-R on screening of depressive and anxiety disorder (mixed) in university students. J Shahrekord Univ Med Sci. $2011 ; 13$ (2): 7-12

6.Shafiee H, Javidi H, Kazemi A. comparison of personality traits and mental health among women and men heart-renal patient in Shahid Faghihi hospital in Shiraz. J Woman Soc. 2011; 2, 62-149.

7.Abiri F, nezami L, fani S. Comparison of six personality dimensions based on the HEXACO model in diabetic and healthy individuals in Bonab city, Iran. J Diab Nurs. 2016; 4 (1): 54-63.

8. Gray JA, McNaughton N. The neuropsychology of anxiety: Anenquiry into the functions of the septo-hippocampal system. Oxford: Oxford University Press; 2000.

9. Motoi M, Egashira Y, Nishimura T, Choi D, Matsumoto R, \& Watanuki S. "Time window for cognitive activity involved in emotional processing". J Physiol Anthropol. 2014; 33, 21-32.

10. Hecht D. "The neural basis of optimism and pessimism". Experimental Neurobiology 2013; 22, 173-199.

11. Ahamadi Tahoor M, Jafari I, Karami Nia R, Akhavan H. The Effect of Positive and Negative Perfectionism and Type D Personality on General Health of the Aged. Avicenna J Clin Med. $2010 ; 17$ (3): 64-69.

12. Dufey M, Fernandez AM, Mourgues C. Assessment of the behavioral inhibition system and the behavioral approach system: adaptation and validation of the Sensitivity to Punishment and Sensitivity to Reward Questionnaire (SPSRQ) in a Chilean sample. Span J Psychol. 2011; 14 (1), $432-440$.

13. Mehrabizadeh Honarmand M, Davoudi I ,Safikhani A. Comparing A, C and D personality types in cardiovascular, cancer, diabetic people and non-ill people of Ahvaz City, In The $2^{\text {nd }}$ scientific conference of psychology students. 2010; 12, 113-14.

14. Erdle S, Rushton JP. The general factor of personality, BIS-BAS, expectancies of reward and punishment, self-esteem, and positive and negative affect. Pers Individ Differ. 2010; 48 (6): $762-6$.

15. Johnson SL, Turner RJ, Iwata N. BIS/BAS levels and psychiatric disorder: An epidemiological study. J Psychopathol Behav Assess. 2003; 25 (1) , 25-36.

16. AghaYousefi A, Oraki M, Mohammadi R. The relationship between the brain behavioral inhibition and activation systems (Bis/Bas) with decision making styles: the moderating effect of handedness. J Neuropsychol. 2015; 1 (2) : 17-31. 
17. Sharifi K, Saidi H. Prediction of psychological well-being based on the orientation of life and optimism. Ro E Ravan J. 2015; 4 (1) : 42-59.

18. Lefebvre G, Lebreton M, Meyniel F, Bourgeois-Gironde S, Palminteri S. Asymmetric reinforcement learning: computational and neural bases of positive life orientation. Nat Hum Behav. 2017; 1(4):0067.

19. Garrett N, Sharot T, Faulkner P, Korn CW, Roiser JP, Dolan RJ. Losing the rose tinted glasses: neural substrates of unbiased belief updating in depression. Front Hum Neurosci. 2014; 8: 1-9.

20. Moutsiana C, Charpentier CJ, Garrett N, Cohen MX, Sharot T. Human frontal-subcortical circuit and asymmetric belief updating. J Neurosci. 2015;35 (42) : 14077-14085.

21. Esmaeilpour Kh, Babapour Kh, Ebrahimi Sarindizaj Z. The relationship between HEXACO personality dimensions and type D personality. J Res Health. 2015; 3, 405-411.

22. Bashiri H. Validating of HEXACO 6- dimensional personality inventory, [dissertation MA in Clinical Psychology]. Mohaghegh Ardabili University; 2010; 150.

23. Carver CS, White TL. Behavioral inhibition, behavioral activation, and affective responses to impending reward and punishment: the BIS/BAS scales. J Pers Soc Psychol. 1994; 67 (2) : 319-333.

24. Scheier MF, Carver CS. Optimism, coping, and health: assessment and implications of generalized outcome expectancies. J Health Psychol. 1985; 4 (3): 219-247.

25. Mousavi Nasab SMH. Optimism - pessimism, stress appraisal and coping strategies: predict psychological adjustment in adolescents. Master's thesis in clinical psychology. Shiraz university; 2005.

26. Ahmadi-Tahoor M, Jafari E, KaramiNia R, Akhavan H. The effect of positive and negative perfectionism and type D personality on general health of the aged people. Dent J Ham Uni Med Sci. $2010 ; 6,17-27$.

27. Corr PJ, Cooper AJ. The Reinforcement Sensitivity Theory of Personality Questionnaire (RSTPQ) : Development and validation. Psychol Assess. 2016; 28 (11): 317-332.

28. Tamir M, Robinson MD, Clore GL. The epistemic benefits of trait-consistent mood states: An analysis of extraversion and mood. J Pers Soc Psychol. 2002; 83 (3) : 663-677.

29. Mohammadlou SS, Gharraee B, Fathali LF, Gohari, MR. The Relationship of Behavioral Activation and Inhibition Systems (BAS/BIS), Difficulty of Emotional Regulation, Metacognition with Worry. Res Cogn Beha Sci. 2013; 3 (2), 85-100.

30. Jaśko K, Czernatowicz-Kukuczka A, Kossowska M, Czarna AZ. Individual differences in response to uncertainty and decision making: The role of behavioral inhibition system and need for closure. Motiv Emot. 2015; 39 (4) : 541-52.

31. Sütterlin S, Andersson S, Vögele C. Inhibition in action-inhibitory components in the behavioral activation system. Behav Brain Sci. 2011; 1 (3) : 160-6.

32. Levita L, Bois C, Healey A, Smyllie E, Papakonstantinou E, Hartley T, Lever C. The Behavioural Inhibition System, anxiety and hippocampal volume in a non-clinical population. Biol Mood Anxi Disord. 2014; 4 (1) : 1-10.

33. Jahanbin S. The relationship between pessimism-optimism and neo-personality traits among housewives and women employed in education organization in Isfahan city in 2014 [MA dissertation]. Islamic Azad University, Khomeini Shahr Branch; 2014.

34. Ashraf Abadi M, Arab H, Behrooz B, Ashraf Abadi F. The relationship between optimism and pessimism with A, B personality types. $1^{\text {st }}$ National Conference on Personality and Modern Life, Sanandaj, Islamic Azad University, Sanandaj Branch, 2012. 